University of Louisville

ThinkIR: The University of Louisville's Institutional Repository

$12-2012$

\title{
Ridge preservation comparing the clinical and histologic healing of an intrasocket allograft vs. a facial overlay xenograft using a bioresorbable barrier membrane.
}

\author{
Evmenios Poulias \\ University of Louisville
}

Follow this and additional works at: https://ir.library.louisville.edu/etd

\section{Recommended Citation}

Poulias, Evmenios, "Ridge preservation comparing the clinical and histologic healing of an intrasocket allograft vs. a facial overlay xenograft using a bioresorbable barrier membrane." (2012). Electronic Theses and Dissertations. Paper 1146.

https://doi.org/10.18297/etd/1146

This Master's Thesis is brought to you for free and open access by ThinkIR: The University of Louisville's Institutional Repository. It has been accepted for inclusion in Electronic Theses and Dissertations by an authorized administrator of ThinkIR: The University of Louisville's Institutional Repository. This title appears here courtesy of the author, who has retained all other copyrights. For more information, please contact thinkir@louisville.edu. 


\title{
RIDGE PRESERVATION COMPARING THE CLINICAL AND HISTOLOGIC HEALING OF AN INTRASOCKET ALLOGRAFT VS. A FACIAL OVERLAY XENOGRAFT USING A BIORESORBABLE BARRIER MEMBRANE
}

\author{
By \\ Evmenios Poulias \\ DDS, University of Athens, Greece 2008
}

\author{
A Thesis \\ Submitted to the Faculty of the \\ School of Dentistry of the University of Louisville \\ in Partial Fulfillment of the Requirements \\ for the Degree of
}

Master of Science

Program in Oral Biology

School of Dentistry

University of Louisville

Louisville, Kentucky

December 2012 
RIDGE PRESERVATION COMPARING THE CLINICAL AND HISTOLOGIC HEALING OF AN INTRASOCKET ALLOGRAFT VS. A FACIAL OVERLAY XENOGRAFT USING A BIORESORBABLE BARRIER MEMBRANE

$$
\text { By }
$$

Evmenios Poulias

DDS, University of Athens, Greece 2008

A Thesis Approved on

September 17, 2012

By the following Thesis Committee:

Henry Greenwell, Thesis Director

Margaret Hill

Ricardo Vidal

Brian S. Shumway

Dean Morton 


\section{DEDICATION}

This manuscript is dedicated to my parents, Nick and Marina, for their loving support and guidance throughout my life. Thank you for being true role models for me and for giving me the opportunity to pursue my dreams. Also, I would like to thank my sister, Dora, for her unconditional love and for always making me laugh. Finally, special thanks to my amazing co-residents, Tommy and Gretchen, for being my partners-incrime and for making me feel like I never left home. I wish you the best from my heart. 


\section{ACKNOWLEDGEMENTS}

I would like to express my sincere gratitude to the following individuals:

Dr. Henry Greenwell, Program Director of Graduate Periodontics, an unwavering mentor, a truly dedicated teacher, who has become a true inspiration for me. It has been an honor for me to study Periodontics under your supervision.

Dr. Margaret Hill, Assistant Program Director, for your enthusiasm, generosity and invaluable guidance over the past 3 years. Thank you for your continuous emotional support and refreshing sense of humor.

Dr. Ricardo Vidal, Assistant Professor, thank you very much for your input into my thesis and for all your help and support during this last year.

Dr. Brian S. Shumway, Assistant Professor, thank you very much for all of your help. Your input into my thesis is greatly appreciated.

Dr. Dean Morton, Professor of Prosthodontics, thank you very much for reading my thesis and for your help and guidance over the last three years. 


\title{
ABSTRACT \\ RIDGE PRESERVATION COMPARING THE CLINICAL AND HISTOLOGIC HEALING OF AN INTRASOCKET ALLOGRAFT VS. A FACIAL OVERLAY XENOGRAFT USING A BIORESORBABLE BARRIER MEMBRANE
}

Evmenios Poulias, DDS

September 17th, 2012

\begin{abstract}
Aim. The efficacy of ridge preservation procedures using grafting materials and barrier membranes has been well established in the literature. However, the loss of horizontal width even with the utilization of intrasocket only guided bone regeneration procedures can lead to loss of soft and hard tissue contour or even compromise implant placement. The primary aim of this study was to compare ridge preservation using an intrasocket mineralized particulate cancellous allograft to an intrasocket mineralized particulate cancellous allograft plus a facial overlay with a particulate bovine xenograft, both covered with a bioresorbable barrier membrane. Clinical and histologic data was used to assess the outcomes.
\end{abstract}

Methods. Twelve positive controls received an intrasocket mineralized cancellous particulate allograft 500-800 $\mu \mathrm{m}$ (Intrasocket group) while twelve test patients received an intrasocket mineralized cancellous particulate allograft 500 to $800 \mu \mathrm{m}$ plus a facial overlay with a particulate bovine xenograft $250-1000 \mu \mathrm{m}$ (Overlay group). All sites 
included in the study were covered with a bioresorbable poly (D,L lactic) acid barrier membrane. Only non-molar sites were included bordered with at least one tooth mesially or distally. Following tooth extraction and at 4-month re-entry, horizontal ridge dimensions were measured with a digital caliper and vertical ridge changes were measured from a resin-fabricated stent. Each site was re-entered for implant placement at about 4 months. Prior to implant placement, a $2.7 \times 6 \mathrm{~mm}$ trephine core was obtained and preserved in formalin for histologic analysis.

Results. The mean horizontal crestal ridge width at the crest for the Intrasocket group decreased from $8.7 \pm 1.0 \mathrm{~mm}$ to $7.1 \pm 1.5 \mathrm{~mm}$ for a mean loss of $1.6 \pm 0.8 \mathrm{~mm}(\mathrm{p}<0.05)$ while the Overlay group decreased from $8.4 \pm 1.4 \mathrm{~mm}$ to $8.1 \pm 1.4 \mathrm{~mm}$ for a mean loss of $0.3 \pm 0.9 \mathrm{~mm}(\mathrm{p}>0.05)$. The difference between the two groups was statistically significant $(p<0.05)$. The mean mid-buccal vertical change for the Intrasocket group was gain of $0.5 \pm 2.9 \mathrm{~mm}(\mathrm{p}>0.05)$ vs. a gain of $0.3 \pm 2.6 \mathrm{~mm}$ for the Overlay group ( $\mathrm{p}$ $>0.05)$. There were no statistically significant differences between groups for vertical change $(p>0.05)$ except for the distal vertical change $(p<0.05)$. Histologic analysis revealed that the Intrasocket group had $35 \pm 16 \%$ vital bone, $21 \pm 13 \%$ non-vital bone, 44 $\pm 9 \%$ trabecular space, while the Overlay group had $40 \pm 16 \%$ vital bone, $17 \pm 11 \%$ nonvital bone, and $43 \pm 12 \%$ trabecular space. There were no statistically significant differences between groups for vital and non-vital bone or for trabecular space $(p>0.05)$. Conclusions. Both treatments were effective in the preservation of horizontal and vertical ridge dimensions at sites for future implant placement. The Overlay group, however, showed significantly better horizontal ridge dimensions compared to the Intrasocket group. The percentage of vital bone achieved was similar for both groups. 


\section{TABLE OF CONTENTS}

PAGE

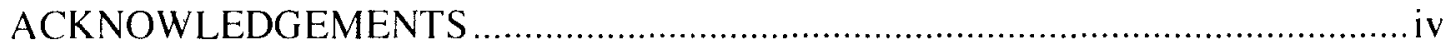

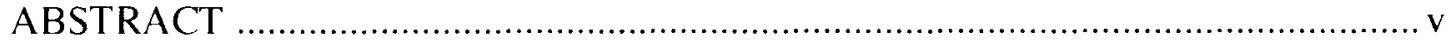

TABLE OF CONTENTS ….............................................................................

LIST OF TABLES

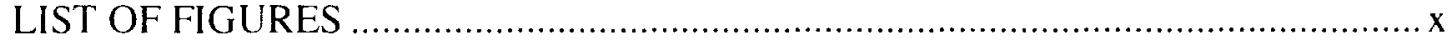

CHAPTER

\section{LITERATURE REVIEW}

Animal Extraction Socket Healing Sequence ………............................ I

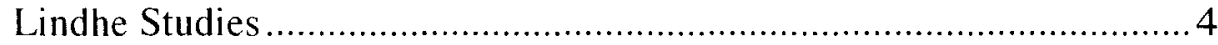

Human Extraction Socket Healing Sequence .........................................5

Alveolar Ridge Resorption following Tooth Extraction .......................... 7

Clinical Studies of Ridge Preservation............................................... 11

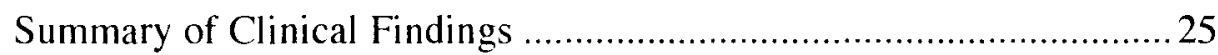

Histologic Evaluation of Ridge Preservation .......................................29

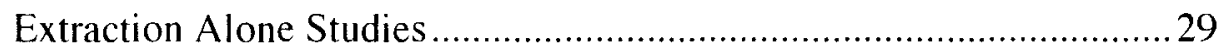

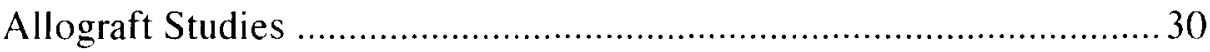

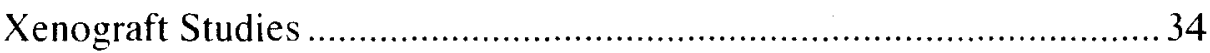

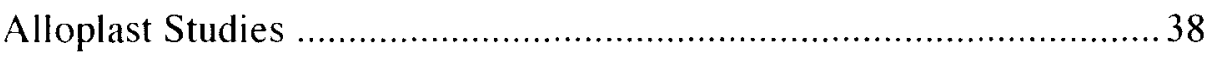

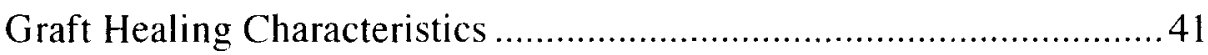

Summary of Histologic Findings ......................................................... 43 
II. MATERIALS AND METHODS

Study Design
Inclusion Criteria
Exclusion Criteria
Post-Surgical Exclusion
Pre-surgical Management
Surgical Treatment
Re-entry Surgery

III. RESULTS …

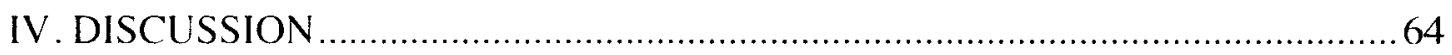

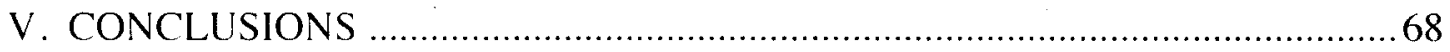

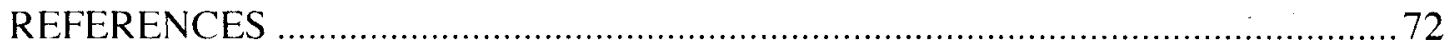

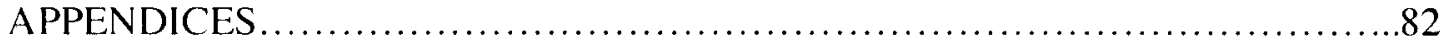

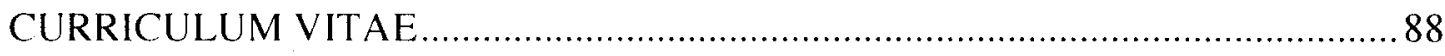




\section{LIST OF TABLES}

TABLE

PAGE

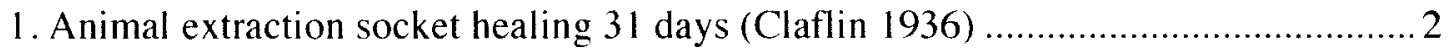

2. Animal extraction socket healing 180 days (Cardaropoli et al. 2003) .......................

3. Animal extraction socket healing 56 days (Araujo \& Lindhe 2005) .......................... 3

4. Human Extraction Socket Healing over 100 Days .................................................. 6

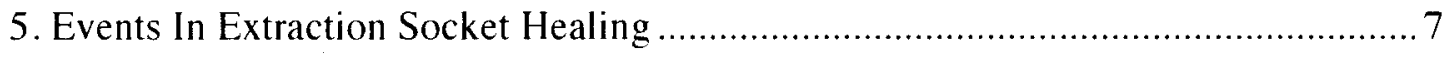

6. Extraction Alone Studies Showing Dimensional Change ..................................... 10

7. Extraction Alone Studies Showing Horizontal Ridge Dimensions ....................... 11

8. Ridge Preservation Studies Showing Change Alone ...........................................22

9. Ridge Preservation Studies Showing Horizontal Ridge Dimensions...................... 23

10. Ridge Preservation Studies Showing Graft Type ……....................................... 24

11. Root Dimensions at the Cervix by Tooth Types ..................................................2 24

12. Horizontal Ridge Width at the Crest for $U$ of L Studies .........................................2 27

13. U of L Studies by Tooth Type (Omitting Poulias Overlay Group) ……………......28

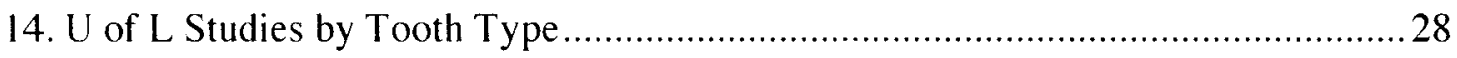

15. Comparison of Human Histologic Data on Extraction Alone Studies ..................... 43

16. Comparison of Histologic Data on Ridge Preservation Studies .............................44

17. Clinical Indices for Intrasocket and Overlay Sites ...............................................5

18. Horizontal Ridge Width for Intrasocket and Overlay Sites ..................................58

19. Vertical Ridge Height Change for Intrasocket and Overlay Sites ..........................59

20. CEJ to Osseous Crest Change at Adjacent Teeth ..................................................6 60

21. Histologic Data at Implant Placement for Intrasocket and Overlay Sites ................61

22. Comparison of Histologic Data from U of L Ridge Preservation Studies ................62

23. Comparison of Histologic Data from U of L Ridge Augmentation Studies ............63 


\section{LIST OF FIGURES}

FIGURE

PAGE

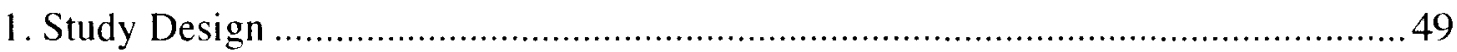

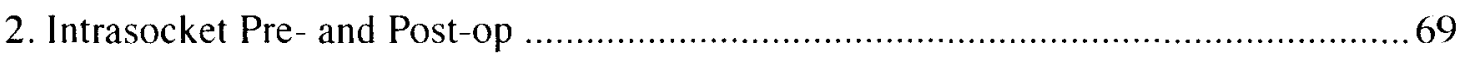

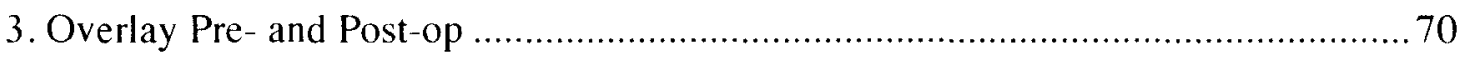

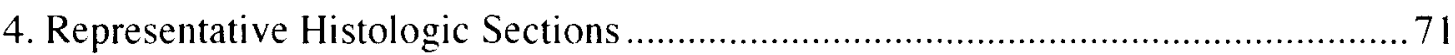




\section{CHAPTER I}

\section{LITERATURE REVIEW}

\section{Animal Extraction Socket Healing Sequence}

Since the 1930's, the healing sequence of the extraction socket has been studied. Claflin (1936) examined the dog extraction socket and provided information regarding the healing up to 31 days (Table 1). The process of healing started with the blood clot formation that was observed on day 1 and continued with the emergence of osteoclasts and fibroblasts. Woven bone formation was noted around 5-7 days followed by complete epithelialization over the clot around 7-9 days as well as complete socket fill by 31 days. In a more recent study. Cardaropoli et al. (2003) studied the changes in the healing process of beagle dog extraction sockets for a total of 180 days (Table 2). In his study as well as in Claflin's study the healing process was initiated with the formation of the blood clot, which was comprised mostly of erythrocytes and platelets. At day 3 vascularized tissue started to replace the clot and by day 7 new blood vessels could be observed. New bone formation on socket walls was not seen until day 14. Confirming Claflin's results Cardaropoli observed the socket completely filled with new bone by day 30. However, at this time point the bone was still immature. It was not until day 90 that the woven bone was replaced by mineralized lamellar bone. The healing process 
continued up to 180 days where due to remodeling lamellar bone was partly replaced with bone marrow.

\section{Table 1}

Animal Extraction Socket Healing 31 Days (Claflin 1936)

\begin{tabular}{|l|l|}
\hline \multicolumn{1}{|c|}{ Time } & \multicolumn{1}{c|}{ Event } \\
\hline Day 1 & Blood clot formation \\
\hline Day 3 & $\begin{array}{l}\text { Osteoclast appear at crest of bone and fibroblast emerge } \\
\text { form socket walls }\end{array}$ \\
\hline Day 5 to 7 & First bone formation \\
\hline Day 7 to 9 & Epithelialization over clot completed \\
\hline Day 11 to 15 & New bone reaching the alveolar crest \\
\hline Day 28 to 31 & Socket filled with new bone, with osteoclasts still present \\
\hline
\end{tabular}

Table 2

Animal Extraction Socket Healing 180 Days (Cardaropoli et al. 2003)

\begin{tabular}{|l|l|}
\hline \multicolumn{1}{|c|}{ Time } & \multicolumn{1}{|c|}{ Event } \\
\hline Day 1 & $\begin{array}{l}\text { Blood clot formation comprised mostly of erythrocytes and } \\
\text { platelets }\end{array}$ \\
\hline Day 3 & Lysis of erythrocytes and clot being replaced by vascularized tissue \\
\hline Day 7 & New blood vessel formation \\
\hline Day 14 & New bone formation on socket walls \\
\hline Day 30 & Socket filled with new bone \\
\hline Day 90 & Woven bone replaced by lamellar bone \\
\hline Day 180 & Some lamellar bone being replaced by bone marrow spaces \\
\hline
\end{tabular}

Lindhe and co-workers have examined extensively the healing of the extraction socket in the dog model. By using 12 sites in 12 mongrel dogs. Araujo and Lindhe (2005) observed the events following tooth extraction over a period of 8 weeks (Table 3 ). At 1 
week, the internal portion of the socket was occupied by blood coagulum, whereas the apical part showed islands of newly formed woven bone adjacent to the bundle bone. At 2 weeks. newly formed woven bone was observed with its surface lined with densely packed osteoblasts. By week 4. extensive complete loss of the crestal bone, which was composed by bundle bone, occurred. Moreover, in the outer surfaces of the buccal and lingual walls, apical to the crestal region, a multitude of osteoclasts were observed. By 8 weeks a zone of mineralized tissue, which consist of a mixture of woven and lamellar bone had formed between the buccal and lingual walls traveling in an oblique direction. The buccal wall was resorbed to a greater extent comparing to the lingual wall resulting in $2 \mathrm{~mm}$ height difference and significant difference in bone width between the two.

\section{Table 3}

Animal Extraction Socket Healing 56 Days (Araujo \& Lindhe 2005)

\begin{tabular}{|c|c|}
\hline Time & Event \\
\hline $\begin{array}{c}\text { Day } 7 \\
\text { (1 week) }\end{array}$ & $\begin{array}{l}\text { - internal portion of the socket occupied by coagulum } \\
\text { - apical portion showed islands of newly formed woven bone } \\
\text { adjacent to the bundle bone. }\end{array}$ \\
\hline $\begin{array}{c}\text { Day } 14 \\
(2 \text { weeks })\end{array}$ & $\begin{array}{l}\text { - apical \& lateral portions showed large amounts of newly formed } \\
\text { woven bone } \\
\text { - surface of the woven bone was lined with densely packed } \\
\text { osteoblasts - primitive bone marrow. }\end{array}$ \\
\hline $\begin{array}{c}\text { Day } 28 \\
\text { (4 weeks) }\end{array}$ & $\begin{array}{l}\text { - at the crestal region, all bundle bone had been lost } \\
\text { - crestal lamellar bone replaced with woven bone. } \\
\text { - apical to the crestal region, a multitude of osteoclasts were } \\
\text { observed on the outer surfaces of the buccal and lingual walls. }\end{array}$ \\
\hline $\begin{array}{c}\text { Day } 56 \\
\text { (8 weeks) }\end{array}$ & $\begin{array}{l}\text { - lingual wall wider than buccal wall } \\
\text { - lingual wall positioned } 2 \text { mm coronal to buccal wall } \\
\text { - zone of mineralized tissue which consist of a mixture of woven } \\
\text { and lamellar bone had formed between the buccal and lingual } \\
\text { walls traveling in an oblique direction. }\end{array}$ \\
\hline
\end{tabular}




\section{Lindhe Studies}

Araujo et al. (2005) also studied the dimensional changes in extraction sockets following immediate implant placement in the dog model. Based on the study design, contralateral extraction sites were selected and observed over a period of 3 months. The first group was comprised of sites that received immediate implant placement after extraction whereas the second group included extraction alone sites. Both groups showed significant resorption resulting in loss of vertical and horizontal height. There were no significant differences between groups at 3 months. However, the most important conclusion of the study was that the immediate implant placement failed to preserve the dimensions of the post-extraction sockets.

In another dog model study by Araujo \& Lindhe (2009), the dimensional alterations using a flap versus a flapless technique were observed over a period of 6 months. Marked changes in the alveolar ridge were noted in both groups with the most significant difference being in the coronal portion. More specifically, the coronal portion of the sockets showed approximately a $35 \%$ reduction in the horizontal dimension. Based on the results of the study, no significant changes were noted between the two techniques in the end of the 6-month period.

Berglundh et al. (1994) studied the vascular supply around Branemark implants in the beagle dog model. According to the observations of this study, the peri-implant mucosa had more blood vessels compared to the peri-implant supracrestal connective tissue, which was almost devoid of vascularity. The peri-implant mucosa vessels were terminal branches from larger vessels originating from the periosteum at the implant site. Carmagnola et al. (2000). by creating sixteen surgical defects in four beagle dogs. 
observed the histologic healing of implants placed in sites previously grafted with particulate mineralized cortical xenograft (Bio-Oss). According to the results of this study, osseointegration failed to occur around the implants. A well-defined connective tissue capsule between the implant surfaces and deep vertical defects were noted instead. Botticelli et al. (2004) observed the healing of surgically created bone configurations around implants. Based on the results of the study, it was concluded that 4 wall defects around implants could be completely resolved after implant placement. Contrary to this, defects characterized with a missing buccal plate showed incomplete healing. Furthermore, Botticelli et al. (2005) observed the effects of implant positioning, surface characteristics and the presence of horizontal and vertical peri-implant defects on osseointegration. Higher level of osseointegration and bone fill was found around roughened surface implants compared to machined implants after 4 months of implant healing. The positioning of the implant in a submerged or non-submerged environment did not affect the healing process considerably. Based on the results of this study, it was concluded that the surface characteristics play a critical role in the amount of osseointegration and bone fill around endosseous implants.

\section{Human Extraction Socket Healing Sequence}

The human extraction socket healing has been evaluated by the three studies discussed below. Amler (1960) studied the histologic healing in 75 human extraction sockets over a period of 50 days. Boyne (1966) examined the healing of one maxillary premolar socket for a period of 23 days in 12 patients requiring complete maxillary 
extractions. In another study by Evian (1982) the healing sequence of 10 patients was observed for a period of 16 weeks. Based on the above studies, a similar pattern to the dog model was noted for the human extraction socket healing sequence. The results are summarized in Table 4 below.

\section{Table 4}

Human Extraction Socket Healing over 100 Days (Evian 1982)

\begin{tabular}{|l|l|}
\hline \multicolumn{1}{|c|}{ Time } & \multicolumn{1}{c|}{ Event } \\
\hline Day 1 & Blood clot formation \\
\hline Day $2-3$ & Granulation tissue appears \\
\hline Day 4 & Contraction of the blood clot begins \\
\hline Day $7-10$ & New bone formation \\
\hline Day 14 & $1 / 3$ socket filled \\
\hline Day 20 & Connective tissue replaces granulation tissue \\
\hline Day 38 & $2 / 3$ socket filled \\
\hline Day 100 & Radiopacity of socket was identical to surrounding bone \\
\hline
\end{tabular}

For both dogs and humans the extraction socket healing started with the formation of the blood clot at day one (Claflin 1936, Amler 1960). After this event, minor time differences were noted in the healing sequence between dog and human studies. Evidence of new bone formation was noted after 5 days in the dog model (Claflin 1936) whereas in humans new bone was observed between 7 and 10 days of healing (Amler 1960). The extraction sockets in the dog model showed complete fill after 30 days of healing (Claflin 1936). However. Amler (1960) observed that only $2 / 3$ of the sockets was filled after 38 days of healing. Mature lamellar bone was evident after 90 days of healing in the dog 
model (Cardaropoli et al. 2003). It was not until after 100 days that mature bone was observed in human extraction sockets (Amler 1960). Table 5 compares the socket healing sequence for the dog and humans models.

Table 5

\section{Events In Extraction Socket Healing}

\begin{tabular}{|c|c|c|c|}
\hline Event & Time & Species & Study \\
\hline \multirow{2}{*}{ Blood Clot Formation } & 0 to 3 days & Dog & Claflin (1936) \\
\hline & 0 to 1 day & Human & Amler et al. (1960) \\
\hline \multirow[b]{2}{*}{ Fibroblast Proliferation } & 3 days & Dog & Claflin (1936) \\
\hline & 2 to 35 days & Human & Amler et al. (1960) \\
\hline Osteoclast activity & 3 to 31 days & Dog & Claflin (1936) \\
\hline \multirow{4}{*}{ Osteoblast activity } & 5 to 31 days & Dog & Claflin (1936) \\
\hline & 7 days & Human & Amler et al. (1960) \\
\hline & 10 days & Human & Boyne (1966) \\
\hline & 28 days & Human & Evian et al. (1982) \\
\hline \multirow{2}{*}{ First evidence of new bone } & 5 days & Dog & Claflin (1936) \\
\hline & $7-10$ days & Human & Amler (1960) \\
\hline Complete socket fill & 30 days & Dogs & Claflin (1936) \\
\hline 1/3 socket fill & 14 days & Human & Boyne (1966) \\
\hline $2 / 3$ socket fill & 38 days & Human & Amler (1960) \\
\hline \multirow{2}{*}{ Mature bone present } & 90 days & Dog & Cardaropoli et al. (2003) \\
\hline & 100 days & Human & Amler (1960) \\
\hline
\end{tabular}

\section{Alveolar Ridge Resorption Following Tooth Extraction}

The dimensional changes of the alveolar bone volume after tooth extraction, has been studied by multiple studies. The alveolar ridge atrophy that is observed in both 
vertical and horizontal dimension can compromise proper implant placement in a prosthetically driven position. Furthermore, the shift of the center of the ridge to a more lingual position can compromise esthetics as well as the occlusal relationship of the restored implants. It has been well documented that the post-extraction alveolar ridge is often lingualized compared to the original ridge (Lekovic et al. 1997, Lekovic et al. 1998, Iasella et al. 2003). In a study by Pietrokovski \& Massler (1967) dental casts were evaluated regarding alveolar ridge changes after extraction. The authors concluded that the buccal aspect of the ridge underwent more resorption than the lingual, independently of maxillary or mandibular arch location. Yilmaz et al. (1998) studied ridge alterations in models, treating 5 patients with 10 single maxillary incisor extraction sites. Based on the results of the study a $17 \%$ decrease in ridge width was noted over a twelve-month period. In another model study, Schropp et al. (2003) evaluated casts from 46 patients with a single premolar or molar extraction for a period of 12 months. It was concluded that $2 / 3$ of the total ridge resorption was observed the first 3 months after extraction. Moreover. according to Ashman (2000), the greatest change in the ridge dimensions occurred within the first 2 years after extraction. Oghli et al. (2010). in a 3-month study, evaluated models of 101 extraction sites where atraumatic extraction alone was performed. They reported a $0.3 \mathrm{~mm}$ decrease in the ridge width. Brugnami et al. (2011) observed 10 extraction alone sites in study models over a period of 6 weeks. Based on the results of the study, the horizontal decrease in width was $0.9 \mathrm{~mm}$. Cardaropoli et al. (2012) in a 4-month model study. evaluated 24 extraction sites and reported $2.1 \mathrm{~mm}$ decrease in width and $1.5 \mathrm{~mm}$ decrease in height. In the literature numerous clinical studies have reported dimensional width change varying from $23-66 \%(2.1 \mathrm{~mm}$ to $4.9 \mathrm{~mm}$ ) after extraction alone (Lekovic 
et al. 1997, Lekovic et al. 1998. Camargo et al. 2000, Iasella et al. 2003. Barone et al. 2008, Pelegrine et al. 2010, Festa et al. 2011, Brownfield \& Weltman 2012, Cardaropoli et al. 2012). Ridge alterations can significantly affect the placement of dental implants in the desired position with severe consequences in occlusion and esthetics. Furthermore, severe bone loss that occurs after extraction might result in the need for an additional surgical guided bone regeneration procedure in order to increase the volume of hard tissue before implant placement. Tables 6 and 7 summarize the data from extraction alone studies and provide information for the horizontal and vertical dimensional ridge changes. 
Table 6

\section{Extraction Alone Studies Showing Dimensional Change}

\begin{tabular}{|c|c|c|c|c|}
\hline \multicolumn{5}{|c|}{ Extraction Alone Studies } \\
\hline Clinical Studies & $\begin{array}{l}\text { Reentry } \\
\text { Time } \\
\text { (months) }\end{array}$ & $\begin{array}{c}\text { Mean Horizontal } \\
\text { Change mm }\end{array}$ & $\begin{array}{c}\text { Percent } \\
\text { Horizontal } \\
\text { Change }\end{array}$ & $\begin{array}{c}\text { Mean Vertical } \\
\text { Change mm }\end{array}$ \\
\hline Lekoric el al. 1997 & 6 & -4.4 & $-62.9 \%$ & -1.0 \\
\hline Lekovic et al. 1998 & 6 & -4.6 & $-61.3 \%$ & -1.5 \\
\hline Camargo et al. 2000 & 6 & -3.1 & $-40.8 \%$ & -1.0 \\
\hline lasella el al. 2003 & $4-6$ & -2.6 & $-28.6 \%$ & -0.9 \\
\hline Serino et al. 2003 & 6 & & & -0.8 \\
\hline Barone et al. 2008 & 7 & -1.5 & $-41.7 \%$ & -3.6 \\
\hline Pelegrine et al. 2010 & 6 & -4.9 & $-66.2 \%$ & -1.2 \\
\hline Festa et al. 2011 & 6 & -3.7 & $-37.4 \%$ & -2.8 \\
\hline Brownfield et al. 2012 & 3 & -2.1 & -2.3 .3 & -1.2 \\
\hline Mean & $5.7 \pm 1.1$ & $-3.7 \pm 1.0$ & $-45 \pm 16$ & $-1.6 \pm 1.0$ \\
\hline \multicolumn{5}{|l|}{ Study Cast Studies } \\
\hline Yilmazet al. 1998 & 12 & -0.8 & -17.0 & -1.4 \\
\hline Schropp et al. 2003 & 12 & -6.1 & -50.8 & 0.4 \\
\hline Oghli et al. 2010 & 3 & -0.3 & & \\
\hline Brugnami et al. 2011 & 1.5 & -0.9 & & \\
\hline Cardaropoli et al. 2012 & 4 & -4.5 & -33.5 & 1.5 \\
\hline Mean & $6.5 \pm 5.1$ & $-2.5 \pm 2.6$ & $-34 \pm 17$ & $0.2 \pm 1.5$ \\
\hline
\end{tabular}


Table 7

Extraction Alone Studies Showing Horizontal Ridge Dimensions

\begin{tabular}{|c|c|c|c|c|c|}
\hline Clinical Studies & $\begin{array}{c}\text { Reentry } \\
\text { Time } \\
\text { (months) }\end{array}$ & $\begin{array}{l}\text { Mean } \\
\text { Initial } \\
\text { Horiz }\end{array}$ & $\begin{array}{c}\text { Mean Fin } \\
\text { Horiz }\end{array}$ & $\begin{array}{c}\text { Mean Horiz } \\
\text { Change }\end{array}$ & $\%$ change \\
\hline l.ckovic et al. 1997 & 6 & 7.0 & 2.6 & -4.4 & -63 \\
\hline I ekovic et al. 1998 & 6 & 7.5 & 2.9 & -4.6 & -61 \\
\hline Camargo et al. 2000 & 6 & 7.5 & 4.4 & -3.1 & -41 \\
\hline Iasella et al. 2003 & 46 & 9.1 & 6.4 & -2.6 & -29 \\
\hline Barone et al. 2008 & 7 & 10.8 & 6.3 & -4.5 & -42 \\
\hline Pelegrine et al. 2010 & 6 & 7.4 & 2.5 & -4.9 & -66 \\
\hline Festa et al. 2011 & 6 & 9.9 & 6.2 & -3.7 & -37 \\
\hline Brownfield et al. 2012 & 3 & 9.0 & 6.9 & -2.1 & -2.3 \\
\hline Mean & $5.7 \pm 1.1$ & $8.5 \pm 1.4$ & $4.8 \pm 1.9$ & $-3.7 \pm 1.0$ & $-45 \pm 16$ \\
\hline
\end{tabular}

\section{Clinical Studies of Ridge Preservation}

It has been well documented in the literature that ridge preservation can prevent alveolar ridge resorption and maintain adequate dimensions for proper implant placement in a well-established restorative position. Even though some resorption can occur with ridge preservation, substantial bone loss is observed when this procedure is not utilized. According to Ashman (2000) when extraction alone takes place without ridge preservation a total of $40-60 \%$ of bone dimension was lost within the first 2-3 years and subsequent loss of $0.25 \%$ to $0.5 \%$ annually. Iasella et al. (2003) in a non-molar study reported up to $4 \mathrm{~mm}$ loss (mean percentage 29\%) in the horizontal dimension in extraction alone sites within 4-6 months. 
One of the most important ways of preserving the osseous contour and wall morphology thereby enhancing the success of the grafting material is the use of an atraumatic tooth extraction technique. Garg (2001), discussing this topic, he proposed the following 5 steps for an atraumatic extraction: 1) do not reflect the interdental papilla, especially in the esthetic zone; 2) focus on the actual process of tooth removal; 3) use elevators and forceps properly to reduce bony involvement and preserve bone contours: 4) section the tooth to help prevent bone loss; and 5) remove any soft tissue fragments or pathology. Horowitz (2005) emphasized the importance of periotomes when attempting an atraumatic extraction. By severing the periodontal fibers the periotome can result in an extraction with significantly less trauma for both the hard and soft tissue. Moreover, it has been well established that the greater the number of bony walls present after extraction. the more likely the osseous graft will be successful in preserving the dimensions of the ridge.

Preservation comparison studies have shown that most. but not all. of the alveolar ridge resorption can be prevented by the use of barrier membranes alone or together with intrasocket grafting materials. Nemcovsky \& Serfaty (1996) treated 23 extraction socket sites with non-resorbable hydroxyapatite (HA) crystals over a period of 12 months. The authors reported a mean horizontal reduction of $0.6 \mathrm{~mm}$. and a mean vertical change of $1.4 \mathrm{~mm}$ over 1 year. Lekovic et al. (1997) in his ridge preservation study compared extraction alone to use of a non-resorbable barrier membrane alone (Gore-Tex). In a follow up study on ridge preservation Lekovic et al. (1998) compared extraction alone to use of a resorbable barrier membrane alone (Resolut). Both of the studies included nonmolar teeth that were extracted atraumatically. After this, the membranes were placed and 
primary closure was achieved. The sites were reentered 6 months post-extraction. Based on the results of the studies there was no significant difference between resorbable and non-resorbable membranes. Based on the results of both studies, there was a mean change in the vertical dimension of $-0.35 \mathrm{~mm}$ and a mean change in the horizontal dimension of $-1.5 \mathrm{~mm}$, which represented a $20 \%$ change of the width. The mean horizontal change for the ePTFE study was $1.7 \mathrm{~mm}$ loss whereas for the Resolut study the mean ridge loss was $1.3 \mathrm{~mm}$. The extraction alone group that was used as a control in these studies had a mean horizontal change of $4.5 \mathrm{~mm}$. The extraction alone sites showed a 2.5 fold width change when compared to non-resorbable membrane sites, while with resorbable membrane sites there was a 3.5 fold width change. Both membrane types achieved a significant decrease in the amount of horizontal and vertical resorption when compared to extraction alone. Camargo et al. (2000) studied 32 non-molar sites in a 6month reentry and compared extraction alone to ridge preservation using bioactive glass (Biogran $(\mathbb{R})$ mixed with calcium sulfate $($ Capset $\mathbb{R})$. The experimental group showed a horizontal reduction of $3.5 \mathrm{~mm} \mathrm{(44.3 \% )}$ and a vertical ridge resorption of $0.4 \mathrm{~mm}$. The extraction alone group showed a horizontal reduction of $3.1 \mathrm{~mm}(41 \%)$ and a vertical ridge resorption of $1 \mathrm{~mm}$ over the period of 6 months. Based on the results of the study it was concluded that the use of bioactive glass mixed with calcium sulfate was not an effective way of preserving the ridge dimensions compared to extraction alone. Simon et al. (2000) used particulate demineralized freeze-dried bone allograft as an intrasocket and a buccal overlay graft covered with a barrier membrane (Resolut XT $\AA$ ) over a period of 4 months. They reported that an initial ridge width of $6.2 \mathrm{~mm}$ increased to $7.3 \mathrm{~mm}$ for a gain of $1.1 \mathrm{~mm}(18 \%)$. Iasella et al. (2003) compared freeze-dried bone allograft 
(FDBA) with a resorbable membrane (Biomend Extend $\mathbb{R}$ ) to extraction alone, by treating 24 non-molar sites over a period of 4-6 months. The authors reported that the FDBA/Biomend group had a mean horizontal reduction of $1.2 \mathrm{~mm} \mathrm{(13 \% )} \mathrm{and} \mathrm{gained} 1.3$ $\mathrm{mm}$ in ridge height whereas the extraction alone group showed a mean horizontal reduction of $2.6 \mathrm{~mm} \mathrm{(41 \% )} \mathrm{and} \mathrm{a} \mathrm{loss} \mathrm{of} 0.9 \mathrm{~mm}$ in ridge height.

In another 4-month preservation study, Zubillaga et al. (2003) treated 11 extraction sockets in 10 patients and compared the use of demineralized bone matrix paste (Regenafil $(\mathbb{R})$ and a resorbable barrier membrane (Resolut $\AA$ ) with or without fixation. Based on the results of the study, there was a mean horizontal resorption of 1.8 $\mathrm{mm}(16.8 \%)$ and a gain of vertical ridge height of $1 \mathrm{~mm}$. Vance et al. (2004) studied 24 non-molar extraction sites. comparing the use of anorganic bovine bone matrix

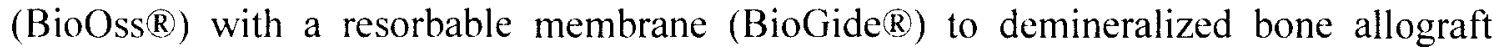
(DFDBA) plus mixture of calcium sulfate and carboxymethylcellulose (CalMatrix ${ }^{\circledR}$ ). Both groups showed a similar horizontal ridge reduction of $0.5 \mathrm{~mm}$. Moreover, the BioOss ${ }^{\circledR}$ group had gain of $0.7 \mathrm{~mm}$ in ridge height whereas the DFDBA/CalMatrix group had a loss of $0.3 \mathrm{~mm}$. Barone et al. (2008), in a 7 month re-entry study, evaluated 40 non-molar extraction sockets and compared corticocancellous porcine bone (MP3®) plus a collagen membrane (Evolution $\mathbb{R}$ ) to extraction alone. Based on the results of this study, the xenograft/collagen membrane group had a horizontal reduction of $2 \mathrm{~mm}$ (23.6\%) and a loss in ridge height of $0.7 \mathrm{~mm}$. The extraction alone group showed horizontal ridge resorption of $4.5 \mathrm{~mm}(42 \%)$ and a loss of $3.6 \mathrm{~mm}$ in ridge height. Brkovic et al. (2008) in a single case report reported no loss in ridge width and height after ridge preservation using a cone of beta-tri-calcium phosphate (TCP) combined with 
type I collagen (RTR Cone ${ }^{\circledR}$ ) without the use of barrier or flap. Cardaropoli \& Cardaropoli (2008) studied extraction sockets treated with corticocancellous porcine bone and a collagen membrane. The mean loss in ridge width was $1.8 \mathrm{~mm}$ over a 4-month period.

Neiva et al. (2008) treated 24 extraction sockets, in a 4 month reentry study, comparing an anorganic bovine-derived hydroxyapatite matrix combined with a synthetic P-15 Putty (PepGen P-15 Putty ${ }^{\mathbb{R}}$ ) and a bioabsorbable collagen wound dressing $\left(\right.$ CollaPlug $\left.{ }^{\mathbb{R}}\right)$ to a bioabsorbable wound dressing alone (CollaPlug( $\left.{ }^{\mathbb{R}}\right)$. The authors reported a loss of $1.3 \mathrm{~mm}$ in ridge width and a gain of $0.2 \mathrm{~mm}$ in ridge height for the experimental group. The bioabsorbable collagen wound dressing alone group showed a $1.4 \mathrm{~mm}$ reduction in horizontal dimension and a loss of $0.56 \mathrm{~mm}$ in ridge height. Fotek et al. (2009) observed 18 non-molar extraction sites grafted with freeze dried bone allograft (Puros $(\mathbb{B})$ and compared the use of an acellular dermal matrix (ADM) as a barrier membrane to the utilization of a polytetrafluoroethylene (PTFE) membrane. The Alloderm group showed $0.44 \mathrm{~mm}$ mean loss of buccal plate width and a loss of $1.11 \mathrm{~mm}$ in ridge height. The polytetrafluoroethylene group showed $0.39 \mathrm{~mm}$ loss of buccal plate width and a loss of $0.25 \mathrm{~mm}$ in ridge height. Mardas et al. (2010) treated 26 patients with ridge preservation and evaluated the results after a period of 8 months. The test group extraction sockets were grafted with a combination of hydroxyapatite (HA) and btricalcium phosphate (b-TCP), whereas the control group sockets were grafted with deproteinized bovine bone mineral (BioOss). All areas were covered with a resorbable collagen membrane (BioGide ${ }^{\circledR}$ ). Based on the results of the study, the horizontal loss for 
the test group was $1.1 \mathrm{~mm}$ and the vertical ridge height loss was $0.1 \mathrm{~mm}$. The control group had a ridge width loss of $2.1 \mathrm{~mm}$ and a gain of $0.25 \mathrm{~mm}$ in vertical height.

Toloue et al. (2011) evaluated 28 extraction sockets grafted with either calcium sulfate (Dentogen, Orthogen $\mathbb{B}$ ) or freeze dried mineralized bone allograft (FDBA) over a period of 3 months. No membrane was used over either material, but a thin layer of calcium sulfate was placed over the FDBA group in order to contain and prevent early loss of the graft particles. For the calcium sulfate group, the authors reported a horizontal reduction of $1.3 \mathrm{~mm}(18.7 \%)$. whereas the FDBA group had a horizontal loss of $1 \mathrm{~mm}$ (14.2\%). The loss in the vertical direction for the calcium sulfate group was $0.23 \mathrm{~mm}$ and for the FDBA group was $0.05 \mathrm{~mm}$. Fernandes et al. (2011), in a 6-month split mouth study, treated 36 extraction sockets comparing the use of an anorganic bovine bone matrix mixed with a synthetic cell-binding peptide P-15 (PepGen P-15()) and covered with an acellular matrix membrane (Alloderm $\mathbb{R}$ ) versus the use of an acellular matrix alone. The PepGen group had a horizontal loss of $2.5 \mathrm{~mm}$ (34.2\%), whereas the Alloderm alone group had a loss in ridge width of $3.4 \mathrm{~mm}(44.7 \%)$. The loss in ridge height for the PepGen group was $1.01 \mathrm{~mm}$ and for the Alloderm alone group $1.19 \mathrm{~mm}$. In another ridge preservation study, Engler-Hamm et al. (2011) evaluated 12 bilateral extraction sites in 11 patients grafted with a composite bone graft of inorganic bovine-derived hydroxyapatite matrix and cell binding peptide P-15 (PepGen P-15( $)$ mixed with demineralized freeze-dried bone allograft (AlloOss $\mathbb{R})$. All sites were covered with a copolymer bioabsorbable membrane that was left exposed in the test group, whereas primary closure was achieved in the control group. After a healing period of 6 months.

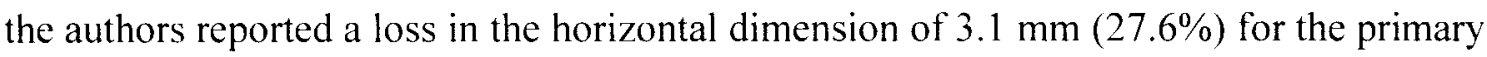


closure group and a loss of $3.4 \mathrm{~mm}(28.5 \%)$ for the membrane exposed group. No significant differences were reported between the two groups concerning the dimensional ridge alterations. Festa et al. (2011), in a 6-month split mouth study, observed 30 extraction sites and compared a corticocancellous porcine bone xenograft (OsteoBiol $\AA$, Gen-Os) associated with a soft cortical membrane (OsteoBiol $\mathbb{R}$, Lamina) to extraction alone. Based on the results of the study, the authors reported a loss in horizontal width of $1.8 \mathrm{~mm}(18.4 \%)$ and a loss in vertical height of $0.55 \mathrm{~mm}$. Gholami et al. (2011), in a 6month split mouth study, treated 28 extraction sockets and compared bovine xenograft $($ BioOss $\mathbb{R})$ to nanocrystalline hydroxyapatite embedded in a silica gel matrix (NanoBone $\left.{ }^{\circledR}\right)$. All sites were covered with a collagen membrane (BioGide $\left.{ }^{\circledR}\right)$. The authors reported a horizontal loss of $1.1 \mathrm{~mm}(13.8 \%)$ for the BioOss group and a loss of $0.9 \mathrm{~mm}$ for the HA group. Nam et al. (2011) treated 44 extraction sites, over a period of 6 months. The test group included 21 sockets treated with deproteinized-bovine-bone mineral $\left(\right.$ BioOss $\left.{ }^{\mathbb{B}}\right)$ coated with synthetic oligopeptide $\left(\right.$ Ossegen-X15 $\left.{ }^{\circledR}\right)$ whereas the control group was grafted with deproteinized-bovine-bone mineral (BioOss $\mathbb{R})$ alone. Both grafted groups were covered with a resorbable collagen membrane (BioGide ${ }^{\circledR}$ ). Based on the results of this study, the loss in the horizontal width for the BioOss/peptide group was $1.2 \mathrm{~mm}(13.2 \%)$, whereas the loss for the BioOss alone group was $1.3 \mathrm{~mm}$ (14.4\%). The vertical loss was $1.2 \mathrm{~mm}$ for the BioOss/peptide group and $2 \mathrm{~mm}$ for the BioOss alone group. Stimmelmayr et al. (2011), in a 5-month case series, treated 39 extraction sites that were grafted with autogenous bone mixed with bovine bone xenograft $(B i o O s s(\mathbb{B})$. The grafts were covered with two barrier layers, the first being a resorbable collagen membrane (BioGide $(\mathbb{B}$ ) and the second layer being a connective 
tissue plug. Based on the results of the study, the loss in the horizontal width that was reported was $1.2 \mathrm{~mm}(17.6 \%)$. Brkovic et al. (2012) evaluated 20 extraction sockets grafted with beta-tricalcium phosphate cones with type I collagen (b-TCP/Clg), 11 of which were left to heal spontaneously and 9 were covered with a barrier membrane (BioGide( $\mathbb{R}$ ). After 9 months of healing, the horizontal loss for the non-membrane group was $1.3 \mathrm{~mm}(16.4 \%)$ and a $0.36 \mathrm{~mm}$ loss in ridge height. For the membrane group, the loss of the ridge width was $0.9 \mathrm{~mm}(11.6 \%)$ and the vertical ridge resorption was 0.25 $\mathrm{mm}$.

Cardaropoli et al. (2012) treated a total of 48 extraction sockets, 24 of which were grafted with combined bovine bone mineral (BioOss) and covered with a porcine collagen membrane (BioGide $\mathbb{R}$ ) and 24 sockets left to heal spontaneously. Based on study casts results, the bovine graft group showed a horizontal loss of $1.04 \mathrm{~mm}(7.70 \%)$ and a gain of $0.46 \mathrm{~mm}$ in height. The extraction alone group had a loss in ridge width of $4.48 \mathrm{~mm}(33.48 \%)$ and a height gain of $1.54 \mathrm{~mm}$. Brownfield \& Weltman (2012), in a 3 month study, observed 20 extraction sockets and compared the use of an osteoinductive demineralized bone matrix with cancellous bone chips (DynaBlast Paste $(\mathbb{B})$ covered with an absorbable collagen wound dressing (CollaTape $(\mathbb{R})$ to extraction alone. The horizontal loss for the allograft group was $1.6 \mathrm{~mm}(17 \%)$, whereas the vertical ridge loss was 0.8 mm. Kutkut et al. (2012) treated a total of 16 patients and compared the use of medicalgrade calcium sulfate hemihydrate mixed with PRP to the use of a collagen resorbable plug dressing material alone over a period of 3 months. The authors reported a horizontal loss of $1.7 \mathrm{~mm}$ and a vertical gain of $0.2 \mathrm{~mm}$ for the test group. On the other hand the control group showed a loss in ridge width of $1.7 \mathrm{~mm}$ and a loss in ridge height of $1 \mathrm{~mm}$. 
Wood \& Mealey (2012), in a 5-month study, observed a total of 40 non-molar extraction sockets, grafted with either FDBA or DFDBA and covered with a collagen membrane. Based on the results of the study, the FDBA group had a ridge width loss of $2.09 \mathrm{~mm}$ (20.9\%), whereas the DFDBA group had a horizontal loss of $2.18 \mathrm{~mm}(22.8 \%)$. Regarding vertical ridge height, the FDBA group had a loss of $0.58 \mathrm{~mm}$ and the DFDBA group a loss of $0.67 \mathrm{~mm}$. Hoang \& Mealey (2012) studied 40 molar extraction sites, 20 of which grafted with human demineralized bone matrix (DBM) putty with particle size between 125 and $710 \mu \mathrm{m}$ (SPS) and 20 sockets grafted with DBM putty. which contained particles $125-710 \mu \mathrm{m}$ and additional particles measuring approximately 2 to $4 \mathrm{~mm}$ in length (MPS). The authors reported a loss of $1.4 \mathrm{~mm}$ in the horizontal dimension and 0.3 $\mathrm{mm}$ in the vertical dimension for the small particle size group, while there was $1.3 \mathrm{~mm}$ horizontal loss and $0.25 \mathrm{~mm}$ loss vertically for the large particle size group (Tables $8,9,10)$.

Three ridge preservation studies shown in Tables 8 and 9 had considerably greater horizontal width change compared to the others. Those studies, which can be considered outliers, showed a loss ranging from $28 \%-44 \%$, which is significantly greater than the mean of $18 \%$ determined from all the studies in Table 8 . Camargo et al. (2000) studied 32 non-molar sites in a 6-month reentry and compared extraction alone to ridge preservation using bioactive glass (Biogran $\mathbb{R}$ ) mixed with calcium sulfate (Capset $\mathbb{R})$. Both groups lost a similar amount of horizontal ridge width. which was $41 \%$ for the extraction alone group and $44 \%$ for the bioactive glass/calcium sulfate group. This significant change for the test group can be explained based on the characteristics of the materials used for the preservation, and more specifically from the fast resorption of the calcium sulfate. 
Fernandes et al. (2011), in a 6-month split mouth study, treated 36 non-molar extraction sockets comparing the use of an anorganic bovine bone matrix mixed with a synthetic cell-binding peptide P-15 (PepGen P-15尺) and covered with an acellular dermal matrix membrane (Alloderm $\mathbb{R}$ ) versus the use of an acellular dermal matrix alone. The test and the positive control group lost $34 \%$ and $45 \%$ of horizontal ridge dimension respectively. A possible explanation for this horizontal width loss might be the use of the acellular dermal matrix material as a barrier membrane, which may have delayed the vascularization process resulting in loss of horizontal ridge dimension. Finally, EnglerHamm et al. (2011) evaluated 12 bilateral extraction sites in 11 patients grafted with a composite bone graft of inorganic bovine-derived hydroxyapatite matrix and cell binding peptide P-15 (PepGen P-15 ${ }^{\circledR}$ ) mixed with demineralized freeze-dried bone allograft (AlloOss $(\mathbb{R})$. A collagen membrane (Resolut $\mathbb{R}$ ) was used in both groups, however it was left exposed in the test group, whereas primary closure was achieved in the control group. The horizontal width change was $29 \%$ for the test group and $28 \%$ for the control group. The loss in horizontal dimensions in this study can be explained due to the inclusion of molar sites in addition to non-molar sites. Furthermore, the use of DFDBA, which is a decalcified allograft that may not hold ridge dimensions as well as the mineralized allografts.

Based on the literature, it has been well documented that with ridge preservation procedures the horizontal and the vertical ridge dimensions can be maintained. However, even with the use of ridge preservation techniques some loss of the dimensions is likely to occur. The extent of bone resorption in both the vertical and horizontal dimension varies between studies and depends on the technique and the material used. In studies that 
ridge preservation was not performed the risk of decreased horizontal and/or vertical dimension significantly increased. 
Table 8

Ridge Preservation Studies Showing Change Alone

\begin{tabular}{|c|c|c|c|c|c|}
\hline Study & Months & Treatment & $\begin{array}{c}\text { Mean } \\
\text { Horizontal } \\
\text { Change } \\
\text { mm }\end{array}$ & $\begin{array}{c}\text { Percent } \\
\text { Horizontal } \\
\text { Change }\end{array}$ & $\begin{array}{c}\text { Mean } \\
\text { Vertical } \\
\text { Change } \\
\text { mm }\end{array}$ \\
\hline Nemcor sky et al. 1996 & 12 & HA nonres & -0.6 & & -1.4 \\
\hline Lekovic et al. 1997 & 6 & ePTFE alone & -1.7 & -2.3 & -0.3 \\
\hline Lekovic et al. 1998 & 6 & Resolut & -1.3 & -18 & -0.4 \\
\hline Camargo et al. 2000 & 6 & Biogran/Capset & -3.5 & -4 & -0.4 \\
\hline Simon el al. 2000 & + & DFDB/Resolut & +1.1 & 18 & \\
\hline Iasella et al. 2003 & 5 & FDBA & -1.2 & -13 & 1.3 \\
\hline Scrino et al. 2003 & 6 & polylac/sponge & & & 1.3 \\
\hline Zubillaga et al. 2003 & + & Regenafil/Resolut & -1.8 & -17 & 1.0 \\
\hline Vance et al. 2004 & + & Calmatrix & -0.5 & -6 & -0.3 \\
\hline Vance et al. 2004 & 4 & BioOss & -0.5 & -5 & 0.7 \\
\hline Barone et al. 2008 & 7 & porcine/coll memb & -2.5 & -24 & -0.7 \\
\hline Cardaropoli el al. 2008 & 4 & porcine/collagen & -1.9 & -16 & \\
\hline Neiva et al. 2008 & 4 & PI5 putty, collapl & -1.3 & & 0.2 \\
\hline Neiva et al. 2008 & + & Collaplug alone & -1.4 & & -0.6 \\
\hline Fotek et al 2009 & 4 & $\mathrm{ADM}+\mathrm{FDBA}$ & & & -1.1 \\
\hline Fotek et al. 2009 & 4 & $\mathrm{PTFE+FDBA}$ & & & -0.3 \\
\hline Pelegrine et al. 2010 & 6 & Auto iliac crest & -1.1 & -15 & -0.6 \\
\hline Beck et al. 2010 & 3 & Puros cancellous & -1.5 & & -0.4 \\
\hline Beck et al. 2010 & 7 & Puros cancellous & -1.4 & & -0.3 \\
\hline Mardas et al. 2010 & 8 & HA/bTCP BioGide & -1.1 & -14 & \\
\hline Mardas et al. 2010 & 8 & BioOss/Biolide & -2.1 & -2.3 & \\
\hline Toloute et al. 2011 & 3 & $\mathrm{CaSO} 4$ & -1.3 & -19 & -0.2 \\
\hline Toloue et al. 2011 & 3 & FDBA & -1.0 & -14 & -0.1 \\
\hline Fernandes et al. 2011 & 6 & $\mathrm{ADM}+\mathrm{ABM} / \mathrm{P}-15$ & -2.5 & -34 & -1.0 \\
\hline Fernandes et al. 2011 & 6 & ADM alone & -3.4 & -45 & -1.2 \\
\hline Engler et al. 2011 & 6 & Resolut.P-15, DFDB & -3.1 & -28 & \\
\hline Engler ct al. 2011 & 6 & Resolut,P-15, DFDB & -3.4 & -29 & \\
\hline Festa et al. 2011 & 6 & Porcine gr/lambone & -1.8 & -18 & -0.6 \\
\hline Gholami et al. 2011 & 6 & BioOss/BioGide & -1.1 & -14 & \\
\hline (iholami et al. 2011 & 6 & Nanobone/BioGide & -0.9 & -1.3 & \\
\hline Nam et al. 2011 & 6 & BioOss/pep/BioGide & -1.2 & -13 & -1.2 \\
\hline Nam et al. 2011 & 6 & BioOss/BioGide & -1.3 & -14 & -2.0 \\
\hline Stimmelmayr et al. $201 \mathrm{l}$ & 5 & Autog//BO/BG/CT & -1.2 & -18 & \\
\hline Brownfield et al. 2012 & 3 & DynaBlast & -1.6 & -17 & -0.8 \\
\hline Brkovic el al. 2012 & 9 & B-TCP cones & -1.3 & -16 & -0.4 \\
\hline Brkovic et al. 2012 & 9 & B-TCP/BioCiide & -0.9 & -12 & -0.3 \\
\hline Kutkut et al. 2012 & 3 & CaSO++PRP & -1.7 & & 0.2 \\
\hline Kutkut et al. 2012 & 3 & Collagen plug & -1.7 & & -1.0 \\
\hline Wood et al.2012 & 5 & FDBA/coll/SRM & -2.1 & -21 & -0.6 \\
\hline Wood et al. 2012 & 5 & DFIDBA & -2.2 & -23 & -0.7 \\
\hline Hoang at al 2012 & 5 & Progenix small & -1.4 & -11 & -0.3 \\
\hline Hoang et al. 2012 & 5 & Progenix Plus large & -1.3 & -12 & -0.3 \\
\hline Mean $\pm s d$ & $5.4 \pm 1.9$ & & $-1.5 \pm 0.9$ & $-18 \pm 11$ & $-0.4 \pm 0.7$ \\
\hline
\end{tabular}


Table 9

\section{Ridge Preservation Studies Showing Horizontal Ridge Dimensions}

\begin{tabular}{|c|c|c|c|c|c|}
\hline Study & Months & $\begin{array}{c}\text { Mean } \\
\text { Horizontal } \\
\text { Initial } \\
\text { mm } \\
\end{array}$ & $\begin{array}{c}\text { Mean } \\
\text { Horizontal } \\
\begin{array}{c}\text { Final } \\
\text { mm }\end{array} \\
\end{array}$ & $\begin{array}{c}\text { Mean } \\
\text { Horizontal } \\
\text { Change } \\
\text { mm } \\
\end{array}$ & $\begin{array}{c}\text { Percent } \\
\text { Horizontal } \\
\text { Change }\end{array}$ \\
\hline Nemcovsky et al. 1996 & 12 & & & -0.6 & \\
\hline Lekovic el al. 1997 & 6 & 7.3 & 5.6 & -1.7 & -2.3 \\
\hline Lekovic et al. 1998 & 6 & 7.4 & 6.1 & -1.3 & -18 \\
\hline Camargo et al. 200 & 6 & 7.9 & 4.4 & -3.5 & 4 \\
\hline Simon et al. 2000 & 4 & 6.2 & 7.3 & +1.1 & 18 \\
\hline Iasella et al 2003 & 5 & 9.2 & 8.0 & -1.2 & -13 \\
\hline Zubillaga et al. 2003 & 4 & 10.7 & 8.9 & -1.8 & -17 \\
\hline Vance et al. 2004 & 4 & 8.9 & 8.4 & -0.5 & -6 \\
\hline Vance ct al. 2004 & 4 & 9.7 & 9.2 & -0.5 & -5 \\
\hline Barone et al. 2008 & 7 & 10.6 & 8.1 & -2.5 & -24 \\
\hline Cardaropoli et al. 2008 & 4 & 11.8 & 9.9 & -1.9 & -16 \\
\hline Neiva et al. 2008 & + & & & -1.3 & \\
\hline Neiva et al. 2008 & 4 & & & -1.4 & \\
\hline Pelegrine et al. 2010 & 6 & 7.4 & 6.3 & -1.1 & -15 \\
\hline Beck et al.2010 & 3 & & & -1.5 & \\
\hline Beck et al. 2010 & 7 & & & -1.4 & \\
\hline Mardas et al. 2010 & 8 & 8.1 & 7.0 & -1.1 & -14 \\
\hline Mardas et al. 2010 & 8 & 9.0 & 6.9 & -2.1 & -23 \\
\hline Toloue et al. 2011 & 3 & 7.1 & 5.8 & -1.3 & -19 \\
\hline Toloue et al. 2011 & 3 & 7.3 & 6.2 & -1.0 & -14 \\
\hline Fernandes et al. 2011 & 6 & 7.4 & 4.9 & -2.5 & -34 \\
\hline Fernandes et al. 2011 & 6 & 7.6 & +.2 & -3.4 & -45 \\
\hline Engler et al. 2011 & 6 & 11.3 & 8.2 & -3.1 & -28 \\
\hline Engler et al. 2011 & 6 & 12.0 & 8.6 & -3.4 & -29 \\
\hline Festa et al. 2011 & 6 & 9.8 & 8.0 & -1.8 & -18 \\
\hline Gholami et al. 2011 & 6 & 7.8 & 6.7 & -1.1 & -14 \\
\hline Gholami et al. 2011 & 6 & 7.4 & 6.4 & -0.9 & -13 \\
\hline Nam et al. 2011 & 6 & 9.1 & 7.9 & -1.2 & -1.3 \\
\hline Nam et al. 2011 & 6 & 9.0 & 7.7 & -1.3 & -14 \\
\hline Stimmelmayr et al. 2011 & 5 & 6.8 & 5.7 & -1.2 & -18 \\
\hline Brownfield et al. 2012 & 3 & 9.4 & 7.8 & -1.6 & -17 \\
\hline Brkovic et al. 2012 & 9 & 7.9 & 6.6 & -1.3 & -16 \\
\hline Brkovic et al. 2012 & 9 & 7.4 & 6.5 & -0.9 & -12 \\
\hline Kutkut et al. 2012 & 3 & & & -1.7 & \\
\hline Kutkut et al.2012 & 3 & & & -1.7 & \\
\hline Wood et al. 2012 & 5 & & & -2.1 & -21 \\
\hline Wood et al. 2012 & 5 & & & -2.2 & -2.3 \\
\hline Hoang at al. 2012 & 5 & 12.2 & 10.8 & -1.4 & -11 \\
\hline Hoang et al. 2012 & 5 & 11.0 & 9.7 & -1.3 & -12 \\
\hline Mean \pm sd & $5.4 \pm 1.9$ & $8.8 \pm 1.7$ & $-7.3 \pm 1.6$ & $-1.5 \pm 0.9$ & $-18 \pm 11$ \\
\hline
\end{tabular}




\section{Table 10}

\section{Ridge Preservation Studies Showing Graft Type}

\begin{tabular}{|l|c|c|c|c|c|c|}
\hline $\begin{array}{l}\text { Graft } \\
\text { Type }\end{array}$ & $\begin{array}{c}\# \\
\text { studies }\end{array}$ & $\begin{array}{c}\text { Initial } \\
\text { Horiz }\end{array}$ & $\begin{array}{c}\text { Final } \\
\text { Horiz }\end{array}$ & $\begin{array}{c}\text { Change } \\
\text { Horiz }\end{array}$ & $\begin{array}{c}\% \\
\text { Change }\end{array}$ & $\begin{array}{c}\text { Change } \\
\text { Vertical }\end{array}$ \\
\hline Autograft & 1 & 7.4 & 6.3 & -1.1 & -15 & -0.6 \\
\hline Allograft & 16 & $9.8 \pm 2.0$ & $8.4 \pm 1.3$ & $-1.4 \pm 1.1$ & $-14 \pm 12$ & $-0.2 \pm 0.7$ \\
\hline Xenograft & 12 & $9.1 \pm 1.5$ & $7.5 \pm 1.5$ & $-1.6 \pm 0.6$ & $-18 \pm 8$ & $-0.6 \pm 0.8$ \\
\hline Alloplast & 6 & $7.7 \pm 0.3$ & $6.2 \pm 1.0$ & $-1.4 \pm 1.1$ & $-20 \pm 14$ & $-0.6 \pm 0.5$ \\
\hline Membrane alone & 3 & $7.4 \pm 0.2$ & $5.3 \pm 1.0$ & $-2.1 \pm 1.1$ & $-29 \pm 14$ & $-0.6 \pm 0.5$ \\
\hline Filler & 5 & 7.1 & 5.8 & $-1.5 \pm 0.2$ & -19 & $-0.1 \pm 0.9$ \\
\hline
\end{tabular}

Horiz = Horizontal

\section{Table 11}

Root Dimensions at the Cervix by Tooth Types (Ash-Wheeler $6^{\text {th }}$ Ed. 1984, Woelfel 1990)

\begin{tabular}{|c|c|c|c|c|}
\hline \multirow[t]{2}{*}{ Tooth Types } & \multicolumn{2}{|c|}{$\begin{array}{c}\text { Bucco-lingual/palatal } \\
\text { dimensions mm }\end{array}$} & \multicolumn{2}{|c|}{$\begin{array}{c}\text { Mesio-distal dimensions } \\
\mathrm{mm}\end{array}$} \\
\hline & Ash-Wheeler & Woelfel & Ash-Wheeler & Woelfel \\
\hline $\begin{array}{l}\text { Mandibular incisors } \\
\text { Central } \\
\text { Lateral }\end{array}$ & $\begin{array}{l}5.3 \\
5.8\end{array}$ & $\begin{array}{l}5.4 \\
5.8 \\
\end{array}$ & $\begin{array}{l}3.5 \\
4.0\end{array}$ & $\begin{array}{l}3.5 \\
3.8\end{array}$ \\
\hline $\begin{array}{l}\text { Maxillary incisors } \\
\text { Central } \\
\text { Lateral }\end{array}$ & $\begin{array}{l}6.0 \\
5.0 \\
\end{array}$ & $\begin{array}{l}6.4 \\
5.8 \\
\end{array}$ & $\begin{array}{l}7.0 \\
5.0\end{array}$ & $\begin{array}{l}6.4 \\
4.7 \\
\end{array}$ \\
\hline $\begin{array}{l}\text { Mandibular \& Maxillary } \\
\text { canines }\end{array}$ & 7.0 & $\begin{array}{l}\text { Mx: } 7.6 \\
\text { Mn: } 7.5\end{array}$ & 5.5 & $\begin{array}{l}M x: 5.6 \\
M n: 5.2\end{array}$ \\
\hline Mandibular $1^{\text {st }}$ premolars & 6.5 & 7.0 & 5.0 & 4.8 \\
\hline Mandibular $2^{\text {nd }}$ premolars & 7.0 & 7.3 & 5.0 & 5.0 \\
\hline $\begin{array}{l}\text { Maxillary premolars }\left(1^{\text {st }} \&\right. \\
\left.2^{\text {nd }}\right)\end{array}$ & 8.0 & $\begin{array}{l}1^{\text {st: }}: 8.2 \\
2^{\text {nd. }}: 8.1\end{array}$ & 5.0 & $\begin{array}{l}1^{\text {st: }}: 4.8 \\
2^{\text {nds }}: 4.7\end{array}$ \\
\hline Mandibular $1^{\text {st }}$ molars & 9.0 & 10.7 & 9.0 & 7.9 \\
\hline
\end{tabular}




\begin{tabular}{|l|c|c|c|c|}
\hline Mandibular 2 $2^{\text {nd }}$ molars & 9.0 & 10.7 & 8.0 & 7.6 \\
\hline Mandibular 3rd molars & 9.0 & 10.4 & 7.5 & 7.2 \\
\hline Maxillary 1 st $^{\text {molars }}$ & 10.0 & 9.0 & 8.0 & 9.2 \\
\hline Maxillary 2 molars & 10.0 & 8.8 & 7.0 & 9.1 \\
\hline Maxillary $3^{\text {rd }}$ molars & 9.5 & 8.9 & 6.5 & 9.2 \\
\hline
\end{tabular}

\section{Summary of Clinical Findings}

Different tooth types possess different bucco-lingual/palatal and mesio-distal dimensions (Table 11). In general, incisors are the smallest, while molars are the widest in dimension. As a result, ridge preservation becomes increasingly critical for the smaller tooth types, especially mandibular incisors, since even a small amount of horizontal ridge resorption can be detrimental.

The main goal of ridge preservation is to minimize the loss of alveolar ridge dimension following extraction. As was evident from the extraction alone studies reviewed (Lekovic et al. 1997, Lekovic et al. 1998, Yilmaz et al. 1998, Camargo et al. 2000 , Iasella et al. 2003, Schropp et al. 2003), the change in ridge width following tooth extraction varies substantially, and this broad range $(30-60 \%)$ may have a profound influence on the future tooth replacement options available.

Despite the use of a bone graft to preserve alveolar ridge dimensions, most studies have reported a net loss in horizontal and/or vertical ridge dimensions. However, Simon et al. (2000) in a 4-month case series study using particulate DFDBA as an intrasocket and a buccal overlay graft along with a barrier membrane (Resolut XT®), reported a horizontal mean net gain of approximately $1.1 \mathrm{~mm}$ of ridge width $3 \mathrm{~mm}$ apical to the 
crest. Moreover, Zubillaga et al. (2003) in another 4-month case series study using demineralized bone matrix (Regenafill@) as an intrasocket and a buccal overlay graft along with a barrier membrane (Resolut XT®) found a horizontal mean net loss of approximately $0.3 \mathrm{~mm}$ at the level of $3 \mathrm{~mm}$ apically to the crest. The results of Zubillaga et al. (2003) compared to Simon et al. (2000) were not as favorable possibly due to the use of Regenafill $(\mathbb{R}$ as a grafting material. According to the authors, the glutaraldehyde cross-linked gelatin carrier in the graft material might have been responsible for the unfavorable healing mainly due to the fact that it hardened very rapidly and did not appear to mix well with patient's blood possibly excluding important healing elements.

The University of Louisville has studied ridge preservation since 2003 (Iasella et al. 2003, Vance et al. 2004, Adams 2005, Siu 2007. Witonsky 2009, Sams 2010, Kotevksa 2011, Poulias 2012). Since that time horizontal ridge width change has ranged from -0.5 to $-2.5 \mathrm{~mm}$ with a mean of $-1.3 \mathrm{~mm}$. The percent change has ranged from $-5 \%$ to $-26 \%$ with a mean of $-15 \%$. A small amount of ridge loss could be due to the small amount of time the flap was open, while a longer surgical procedure may lead to more bone loss (Table 12). Another factor in varying results is tooth type. According to the University of Louisville studies (Table 13,14), maxillary tooth types compared to the same mandibular tooth types had a greater percentage ridge width loss. Thus, results of a study could vary based on the distribution of teeth in the sample (Table 13,14). 
Table 12

Horizontal Ridge Width at the Crest for $U$ of $L$ Studies

Mean $\pm \mathrm{sd}$ in $\mathbf{m m}$

\begin{tabular}{|llllc|}
\hline & Initial & Final & Change & \% Change \\
\hline Iasella 2003 FDBA & & & & \\
Vance 2004 CalMatrix & $9.2 \pm 1.2$ & $8.0 \pm 1.4$ & $-1.2 \pm 0.9$ & -1.3 \\
Vance 2004 BioGide/BioOss & $8.9 \pm 1.8$ & $8.4 \pm 1.5$ & $-0.5 \pm 0.7$ & -6 \\
Adams 2005 Intra FDBA & $9.7 \pm 1.1$ & $9.2 \pm 1.1$ & $-0.5 \pm 0.8$ & -5 \\
Adams 2005 Overlay FDBA & $9.4 \pm 1.2$ & $7.4 \pm 1.5$ & $-2.0 \pm 0.9^{*}$ & -21 \\
Siu 2007 Flap & $8.5 \pm 1.0$ & $7.1 \pm 1.2$ & $-1.4 \pm 1.0^{*}$ & -17 \\
Siu 2007 Flapless & $8.5 \pm 1.5$ & $7.5 \pm 1.5$ & $-1.0 \pm 1.1$ & -12 \\
Witonsky 2009 BioCol & $8.3 \pm 1.3$ & $7.0 \pm 1.9$ & $-1.3 \pm 1.0$ & -16 \\
Witonsky 2009 PTFE & $8.6 \pm 1.0$ & $7.3 \pm 1.0$ & $-1.3 \pm 0.9$ & -1.5 \\
Sams 2010 Cortical & $7.9 \pm 1.5$ & $6.8 \pm 1.4$ & $-1.1 \pm 1.1$ & -14 \\
Sams 2010 Cancellous & $8.6 \pm 2.0$ & $6.7 \pm 2.3$ & $-1.9 \pm 1.4$ & -2.3 \\
Kotevska 2011 Demineralized & $8.4 \pm 1.1$ & $6.3 \pm 1.6$ & $-2.0 \pm 1.6$ & -24 \\
Kotevska 2011 Cancellous & $9.1 \pm 1.4$ & $6.7 \pm 1.6$ & $-2.5 \pm 1.7^{*}$ & -26 \\
Poulias 2012 Overlay & $8.2 \pm 1.5$ & $6.9 \pm 1.5$ & $-1.3 \pm 1.4^{*}$ & -15 \\
Poulias 2012 Intrasocket & $8.4 \pm 1.4$ & $8.1 \pm 1.4$ & $-0.3 \pm 0.9$ & -3 \\
\hline Mean & $8.7 \pm 1.0$ & $7.1 \pm 1.5$ & $-1.6 \pm 0.8$ & -19 \\
\hline
\end{tabular}

$*=p<0.05$ between initial and 4 month values 
Table 13

U of L Studies by Tooth Type (Horizontal Change)*

Mean $\pm \mathrm{sd}$ in $\mathrm{mm}$

\begin{tabular}{|lccccc|}
\hline & n & Initial & Final & Change & \% Change \\
\hline Maxillary Incisor & 38 & $7.7 \pm 1.0$ & $5.8 \pm 1.4$ & $-1.9 \pm 1.2$ & $-24 \pm 1.5$ \\
Mandibular Incisor & 2 & $5.9 \pm 0.2$ & $5.1 \pm 0.0$ & $-0.9 \pm 0.2$ & $-15 \pm .3$ \\
Maxillary Canine & 8 & $8.8 \pm 0.7$ & $6.4 \pm 2.1$ & $-2.4 \pm 2.0$ & $-28 \pm 22$ \\
Mandibular Canine & 3 & $7.8 \pm 1.8$ & $7.0 \pm 2.5$ & $-0.8 \pm 1.7$ & $-10 \pm 2.3$ \\
Maxillary Premolar & 99 & $9.4 \pm 1.2$ & $8.0 \pm 1.3$ & $-1.4 \pm 1.1$ & $-14 \pm 11$ \\
Mandibular Premolar & $2+$ & $7.8 \pm 1.3$ & $7.4 \pm 1.3$ & $-0.4 \pm 1.0$ & $-4 \pm 1.3$ \\
\hline
\end{tabular}

*Omitting Poulias overlay group

Table 14

U of L Studies by Tooth Type (Horizontal Change)

Mean \pm sd in $\mathbf{m m}$

\begin{tabular}{|lccccc|}
\hline & n & Initial & Final & Change & \% Change \\
\hline Maxillary Incisor & 42 & $7.7 \pm 1.0$ & $6.0 \pm 1.4$ & $-1.7 \pm 1.3$ & $-22 \pm 16$ \\
Mandibular Incisor & 2 & $5.9 \pm 0.2$ & $5.1 \pm 0.0$ & $-0.9 \pm 0.2$ & $-1.5 \pm 3$ \\
Maxillary Canine & 9 & $8.8 \pm 0.7$ & $6.4 \pm 2.1$ & $-2.4 \pm 1.9$ & $-27 \pm 21$ \\
Mandibular Canine & 3 & $7.8 \pm 1.8$ & $7.0 \pm 2.5$ & $-0.8 \pm 1.7$ & $-10 \pm 2.3$ \\
Maxillary Premolar & 105 & $9.4 \pm 1.2$ & $8.1 \pm 1.3$ & $-1.3 \pm 1.1$ & $-14 \pm 11$ \\
Mandibular Premolar & 24 & $7.8 \pm 1 . .3$ & $7.4 \pm 1.3$ & $-0.4 \pm 1.0$ & $-4 \pm 13$ \\
\hline
\end{tabular}




\section{Histologic Evaluation of Ridge Preservation}

Histologic evaluation of bone quality is an essential element when determining the most appropriate grafting material for utilization during ridge preservation procedures. Ideally, the graft material should have a quick turnover, minimizing residual particles after healing and enhancing the formation of vital bone. Bone quality also is an important factor affecting the placement and the success of dental implants. I.ekholm \& Zarb (1985) described a bone quality index including the following four types: Type I bone (homogenous compact bone), Type II bone (thick layer of compact bone surrounding a core of dense trabecular bone). Type III bone (thin layer of cortical bone surrounding dense trabecular bone of favorable strength) and Type IV bone (thin layer of cortical bone surrounding a low-density trabecular bone). According to this study, Type I bone is most preferred for implant placement since it has the highest density of cortical bone and Type IV is the least preferred due to its very low density.

\section{Extraction Alone Studies}

According to extraction alone studies, the percentage of vital bone after 4-8 months of healing ranged from 26-54\% whereas the percentage of trabecular space ranged from 46-85\%. (Table 11) More specifically, Froum et al. (2002), in a 6-8 month study reported $32.4 \%$ vital bone and $67.6 \%$ trabecular space. Iasella et al. (2003) reported $54 \%$ vital bone and 46\% trabecular space over 4-6 months of healing. Serino et al. (2003) reported $44 \%$ vital bone and $56 \%$ trabecular space in a 6-month healing study. 
Cardaropoli et al. (2003), in a canine animal study, reported 15\% vital bone and $85 \%$ trabecular space over a period of 6 months. Barone et al. (2008) reported $26 \%$ vital bone and 59\% trabecular space in a 7-month healing study. Crespi et al. (2009), in a 3-month study, reported 33\% vital bone and 65\% trabecular space. Pelegrine et al. (2010) reported $43 \%$ vital bone and $57 \%$ trabecular space over a period of 6 months. Heberer et al. (2011), in a 4-month study, reported $44 \%$ vital bone and $56 \%$ trabecular space. Crespi et al. (2011b), in a 4-month study, reported $30.3 \%$ vital bone and $58.3 \%$ trabecular space. Brownfield \& Weltman (2012), in a 3-month study, reported 35.5\% vital bone and $64.6 \%$ trabecular space. Cardaropoli et al. (2012) in a 4 -month study reported $43.82 \%$ vital bone and $56.17 \%$ trabecular space. It has been postulated that the lack of load in the edentulous area is responsible for the large amount of trabecular space.

\section{Allograft Studies}

Both mineralized particulate freeze-dried bone allograft (FDBA) and demineralized particulate freeze-dried bone allograft (DFDBA) have been used widely for ridge preservation procedures. Based on the graft abilities, both allografts are known for their osteoconductive properties providing a scaffold during bone turnover and healing (Mellonig et al. 1981, Mellonig 1991). However, it has been suggested that DFDBA has also osteoinductive properties due to the presence of bone morphogenetic proteins (BMPs).

Urist (1965) isolated BMPs by decalcifying long bone from rabbits. rats, pigs. calf and human cortical bone. In a subsequent study, Urist \& Strates (1971) identified BMPs 
from human cortical bone and then placed them in ectopic sites in athymic mice where they induced new bone formation. The osteoinductive potential of the DFDBA is affected by age and health status as well. More specifically, donors over the age of 50 showed significantly less induction ability. It has also been reported in the literature that commercial DFDBA batches from different bone banks differ in both size and ability to induce new bone formation. Gender has no effect on the ability of DFDBA to induce bone (Schwartz et al. 1996, 1998, 2000).

According to the literature, histologic evaluation of extraction sites grafted with demineralized freeze-dried bone allograft (DFDBA) has led to conflicting results regarding bone healing. Smukler et al. 1999 as well as Froum et al. 2002 reported a significant amount of residual DFDBA particles present after bone healing. Moreover. Becker et al. (1998) observed fibrous encapsulation of DFDBA particles with no evidence of osteoblastic or osteoclastic activity. It was therefore suggested, that DFDBA might affect bone to implant contact and interfere with socket healing (Becker et al. 1994 , 1996, 1998). However, other studies have shown resorption of the residual graft particles and a large percentage of vital bone (Vance et al. 2004). Histologically, in several cases, DFDBA particles are in an intimate contact with newly formed woven and lamellar bone with distinct cement lines and lack of encapsulation in dense connective tissue. Moreover, osteoblasts were lining the endosteal spaces and the bone marrow exhibited a mild degree of fibrosis without signs of an inflammatory reaction (Brugnami et al. 1996, 1999. Smukler et al. 1999, Froum et al. 2002) reported 34.7\% vital bone. $51.8 \%$ trabecular space and 13.5\% non-vital bone after a period of 6-8 months of healing. Vance et al. (2004), in a 4-month study, observed 12 extraction sites grafted with a mixture of 
DFDBA and putty consisting of calcium sulfate and carboxymethylcellulose (CalMatrix ${ }^{\mathbb{R}}$ ). The authors reported $61 \%$ vital bone. $36 \%$ trabecular space and only $3 \%$ residual grafting material. Overall in the literature the percentage of the vital bone after ridge preservation with DFDBA ranged from $35 \%$ to $60 \%$ whereas non-vital bone ranged from $3 \%$ to $14 \%$. The presence of more residual DFDBA graft particles and fibrous encapsulation might be attributed to the failure to use an occlusive barrier membrane (Becker et al. 1996. 1998). Engler-Hamm et al. (2011) studied 12 bilateral extraction sites grafted with a composite bone graft of inorganic bovine-derived hydroxyapatite matrix and cell binding peptide P-15 (ABM/P-15) and covered with copolymer bioabsorbable membrane (Resolut). Primary closure was achieved at the control group, whereas test sites left the membrane exposed. After 6 months of healing, the primary closure group showed $44 \%$ vital bone, $15.5 \%$ residual graft and $40.5 \%$ trabecular space, whereas the exposed-membrane sites showed $52.8 \%$ vital bone, $6.4 \%$ residual graft and $40.8 \%$ trabecular space. In a more recent study, Wood \& Mealey (2012), in a 5-month study, observed a total of 40 non-molar extraction sockets, grafted with either FDBA or DFDBA and covered with a collagen membrane. From the 40 grafted sites the authors gathered 32 core biopsies ( 16 in each group) and evaluated them histologically. For the DFDBA group the authors reported $38.42 \%$ vital bone, $8.88 \%$ residual graft and $52.71 \%$ trabecular space. For the FDBA group, they reported $24.63 \%$ vital bone, $25.42 \%$ residual graft and $49.94 \%$ trabecular space. Based on the results of this study, sites grafted with DFDBA showed more vital bone and less residual graft when compared with FDBA. Moreover, Hoang \& Mealey (2012) studied 40 molar extraction sites, 20 of which grafted with human demineralized bone matrix (DBM) putty with particle size between 125 and 
$710 \mu \mathrm{m}$ (SPS) and 20 sockets grafted with DBM putty, which contained particles 125$710 \mu \mathrm{m}$ and additional particles measuring approximately 2 to $4 \mathrm{~mm}$ in length (MPS). The one-size bone particle group (SPS) showed $49 \%$ vital bone, $8 \%$ residual graft and $43 \%$ trabecular space. The multiple-size bone particle group showed 53\% vital bone, $5 \%$ residual graft and $43 \%$ trabecular space. Brownfield \& Weltman (2012), in a 3-month study, observed 10 extraction sockets grafted with allograft paste, composed of osteoinductive demineralized bone matrix with cancellous bone chips (DynaBlast Paste $(\mathbb{R})$ and covered with an absorbable collagen wound dressing (CollaTape ${ }^{\mathbb{R}}$ ). The authors reported $37.4 \%$ vital bone, $4.5 \%$ non-vital bone and $58.2 \%$ trabecular space.

Mineralized freeze-dried particulate bone allograft ridge preservation studies have reported vital bone ranging from $28-69 \%$. trabecular space ranging from $27-58 \%$ and non-vital bone ranging from $3.8-34.7 \%$. In most of the studies the residual FDBA particles were often surrounded by vital woven or lamellar bone, or they were encapsulated in dense fibrous tissue. lasella et al. (2003) examined the histologic healing of 12 sockets grafted with FDBA and covered with a resorbable membrane (Biomend Extend $(\mathbb{R})$ over a period of $4-6$ months. The authors reported $30.1 \%$ of vital bone, $34.7 \%$ non-vital bone and $35.2 \%$ trabecular space. Wang \& Sao (2008) treated 5 patients with solvent preserved mineralized particulate cancellous allograft (Puros $\left.{ }^{\circledR}\right)$ and evaluated the healing after a period of 5-6 months. The percentage of vital bone was $69 \%$. non-vital bone was $3.8 \%$ and $27 \%$ was trabecular space. Fotek et al. (2009) observed 18 non-molar extraction sites grafted with freeze dried bone allograft (Puros $\left.{ }^{\circledR}\right)$ and compared the use of an acellular dermal matrix (ADM) as a barrier membrane to the utilization of a polytetrafluoroethylene (PTFE) membrane. The authors reported similar results for both 
groups. More specifically, the alloderm group showed $28 \%$ vital bone, $14 \%$ non-vital bone and $58 \%$ trabecular space. The PTFE group showed 33\% vital bone, $15 \%$ non-vital bone and 52\% trabecular space. Beck \& Mealey (2010) evaluated histologically 38 extraction sites grafted with mineralized particulate bone allograft (Puros $\mathbb{R}$ ) and covered with a double layer of bioabsorbable collagen wound dressing (Colla Tape $\left.{ }^{\circledR}\right)$. The first group consisted of 16 sites that were allowed to heal for 3.5 months (early healing) whereas the second group consisted of 22 sites that healed for a total of 7 months (delayed healing). The early healing group had $45.8 \%$ vital bone, $14.6 \%$ non-vital bone and $39.6 \%$ trabecular space. The delayed healing group had $45 \%$ vital bone, 13.5 nonvital bone and 41.3\% trabecular space. Toloue et al. (2011) examined histologically 15 extraction sites grafted with FDBA and covered with calcium sulfate. After 3 months of healing, they reported $16.7 \%$ vital bone, $21.4 \%$ residual graft material and $61.6 \%$ trabecular space. Wood \& Mealey (2012), in a 5-month study, observed a total of 40 nonmolar extraction sockets, grafted with either FDBA or DFDBA and covered with a collagen membrane. For the FDBA group, they reported $24.63 \%$ vital bone, $25.42 \%$ residual graft and $49.94 \%$ trabecular space.

\section{Xenograft Studies}

Xenografts have been widely used in ridge preservation studies with conflicting results. The main property attributed to xenografts is their ability to provide a scaffold for new bone formation. Evidence of osteoconductivity based on osseous ingrowth and close integration with newly formed bone has been reported in the literature (Table). Artzi et al. 
(2000) evaluated 15 sockets in 15 patients treated with BioOss over a period of 9 months. The authors reported $46.3 \%$ vital bone, $30.8 \%$ non-vital bone and $42.6 \%$ trabecular space. Zitzmann et al. (2001) treated 6 sockets with BioOss, in a 6-month study and found $26.9 \%$ vital bone, $30.5 \%$ non-vital bone and $42.6 \%$ trabecular space. In another ridge preservation study, Froum et al. (2004) studied 8 extraction sockets grafted with a nonresorbable anorganic bovine bone substitute (OsteoGraf R/N-300ß) and compared an ePTFE barrier membrane to Alloderm ${ }^{\circledR}(\mathrm{ADM})$ as a occlusive barrier. After 7 months of healing they reported $18 \%$ vital bone, $21 \%$ non-vital bone and $61 \%$ trabecular bone for the ePTFE group. The percentages for the Alloderm group were $42 \%$ vital bone, $13 \%$ non-vital bone and $45 \%$ trabecular space. Vance et al. (2004) reported that for the BioOss extraction sockets group. vital bone was $26 \%$, non-vital bone $16 \%$ and trabecular space $54 \%$ after 4 months of healing. Barone et al. (2008) treated 20 non-molar extraction sites with corticocancellous porcine bone (MP3 $\mathbb{R}$ ) plus a collagen membrane (Evolution $(\mathbb{R})$ and compared the results to 20 sites that were treated with extraction alone. After 7 months, the authors reported $35.5 \%$ vital bone, $29.2 \%$ non-vital bone and $36.6 \%$ trabecular space for the xenograft group. Cardaropoli (2008) studied extraction sockets treated with corticocancellous porcine bone and a collagen membrane over a period of 4 months. Even though in this study the authors did not report the percentages of vital bone or trabecular space, they reported $24.5 \%$ of residual grafting material (non-vital bone). Araujo et al. (2008) evaluated extraction sockets in mongrel dogs treated with BioOss

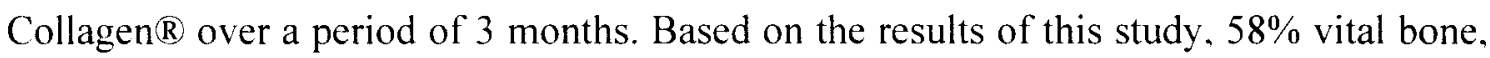
$12 \%$ non-vital bone and $27 \%$ trabecular space was observed. The authors attributed the high percentage of vital bone to the incorporation of collagen into the BioOss $\mathbb{R}$. Neiva et 
al. (2008) treated 24 extraction sockets, comparing an anorganic bovine-derived hydroxyapatite matrix combined with a synthetic P-15 Putty (PepGen P-15 Putty®) and a bioabsorbable collagen wound dressing (CollaPlug $\mathbb{R}$ ) to a bioabsorbable wound dressing alone (CollaPlug $(\mathbb{R})$. After 4 months of healing the xenograft group had $29.9 \%$ vital bone, $6.3 \%$ non-vital bone and $65.3 \%$ trabecular space. Nevins et al. (2009) evaluated 8 extraction sites grafted with a mineralized collagen substitute (BioOss Collagen) combined with platelet-derived growth factor-BB without a barrier. Nevins reported $20 \%$ vital bone, $13.3 \%$ non-vital bone and $66 \%$ trabecular space after $4-6$ months of healing. McAllister et al. (2010), in a 3-month study, grafted 12 extraction sockets with BioOss combined with platelet-derived growth factor (PDGF). Based on the results of the study, vital bone was $24 \%$. non-vital bone was $17 \%$ and trabecular space was $59 \%$. Araujo \& Lindhe (2011) in another beagle dog ridge preservation study grafted one side with BioOss Collagen and the other side with autologous bone. After 3 months of healing, they reported $45 \%$ vital bone, $24 \%$ non-vital bone and $18 \%$ trabecular space for the xenograft group. Heberer et al. (2011), in a 4-month study, evaluated grafting of 20 sockets with BioOss collagen to extraction alone. The BioOss Collagen group had 25\% vital bone, $15 \%$ non-vital bone and $60 \%$ trabecular space. By combining all human studies together grafting with xenografts resulted in vital bone percentage ranging from 18-46.3\%, non-vital bone ranged from $6.3-30.8 \%$ and trabecular space from $36.6-66 \%$. Overall, it has been suggested in the literature that the duration of the healing after a ridge preservation procedure affects directly the percentage of vital bone in extraction sockets grafted with xenografts. Gholami et al. (2011), in a 6-month study, observed histologically 14 extraction sockets grafted with bovine xenograft (BioOss $(\mathbb{R})$ and 
covered with a collagen membrane (BioGide $\left.{ }^{\circledR}\right)$. After 6 months of healing. they reported $27.4 \%$ vital bone, $20.6 \%$ residual graft and $52 \%$ trabecular space. In another study by Crespi et al. (2011a), 15 sockets were grafted with corticocancellous porcine bone (Tecnoss $(\mathbb{R})$ and covered with a collagen sheet membrane (Condress $\mathbb{B})$, whereas 15 sockets were covered with the collagen sheet membrane alone (Condress ${ }^{\circledR}$ ). After 4 months of healing, the authors reported for the porcine graft group $39.6 \%$ vital bone, $34.4 \%$ residual graft material and $26.0 \%$ trabecular space. The membrane alone group showed $29.5 \%$ vital bone and $57.7 \%$ trabecular space. Crespi et al. (2011 b), in a 4-month split mouth study, evaluated histologically 15 sockets grafted with corticocancellous porcine bone (Tecnoss $\widehat{\mathbb{B}})$. Based on the results of the study, vital bone was $38 \%$, nonvital bone was $36.6 \%$ and trabecular space was $25.3 \%$. Nam et al. (2011) evaluated 44 extraction sites, over a period of 6 months. The test group included 21 sockets treated with deproteinized-bovine-bone mineral (BioOss $\mathbb{B}$ ) coated with synthetic oligopeptide (Ossegen-X15(R) whereas the control group was grafted with deproteinized-bovine-bone mineral (BioOss $(\mathbb{R})$ alone. Both grafted groups were covered with a resorbable collagen membrane (BioGide $\mathbb{R})$. The authors reported $10.4 \%$ vital bone, $18.7 \%$ non-vital bone and $70.8 \%$ trabecular space for the test group and $5.3 \%$ vital bone, $16.4 \%$ non-vital bone and $78.3 \%$ trabecular space for the control group. Cardaropoli et al. (2012) observed 24 sockets grafted with combined bovine bone mineral (BioOss Collagen) and covered with a porcine collagen membrane (BioGide) over a period of 4 months. Based on the results of this study, vital bone was $26.34 \%$, residual graft was $18.46 \%$ and trabecular space was $55.19 \%$. 


\section{Alloplast Studies}

Alloplasts have been as well widely used in ridge preservation studies. Materials such as calcium sulfate, hydroxyapatite (HA) and bioactive glass have been evaluated for their ability to preserve the alveolar ridge after extraction and promote the formation of new vital bone. Alloplasts have no osteoinductive or osteogenic properties. Their main attribute is osteoconduction, serving as a scaffold for new bone formation. According to the results of the different studies in the literature those materials have been shown to produce vital bone formation from 25 to $63 \%$ (Table). Guarnieri et al. (2004) evaluated 10 extraction sites grafted with medical grade calcium sulfate hemihydrate after 3 months and reported $58 \%$ vital bone and no residual graft particles due to its fast resorption compared to the other types of alloplasts. On the contrary, hydroxyapatite has a slower resorption rate as reported in the alloplast studies. MacNeil et al. (1999) evaluated the healing process of 4 different alloplast materials: hydroxyapatite (HA, OsteoGraf/Pß),

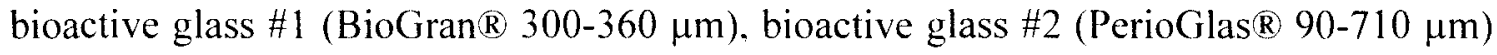
and calcium sulfate $($ Capset $\mathbb{R})$ with autogenous bone, in osteotomy sites surgically created in the rabbit tibia over 28 days. Capset $\mathbb{R}$ plus autogenous bone showed the greatest mean percentage of vital bone $(58.8 \%)$ whereas PerioGlas $(\mathbb{R})$ showed the least

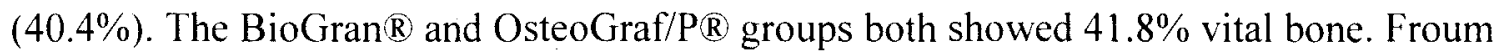
et al. (2002) examined 19 human extraction sites grafted with Biogran $\mathbb{R}$. After 6-8 months of healing, vital bone was $59 \%$, non-vital bone was $6 \%$ and trabecular bone was 35\%. Serino et al. (2003) grafted 34 extraction sockets with a bioabsorbable polylactide/polyglycolide acid sponge (Fisiograft $(\mathbb{R})$. The authors reported $67 \%$ vital bone 
and $33 \%$ trabecular bone after 6 months of healing. No residual graft particles were noted. Froum et al. (2004) evaluated 8 sockets grafted with absorbable HA (OsteoGraf $\left.R / L D{ }^{\circledR}\right)$ and covered with either an Alloderm ${ }^{\circledR}(A D M)$ or an ePTFE barrier membrane. After 4 months of healing, the HA/ADM group had 35\% vital bone, $4 \%$ non-vital bone and $62 \%$ trabecular space. The HA/ePTFE group showed $28 \%$ vital bone, $12 \%$ non-vital bone and $61 \%$ trabecular space. Luczyszyn et al. (2005), in a 6 month study, grafted extraction sockets with hydroxyapatite (Algipore $\mathbb{R}$ ) and used Alloderm $(\mathbb{R})(A D M)$ as an occlusal barrier. Luczyszyn reported $1 \%$ of vital bone. $42 \%$ non-vital bone and $57 \%$ trabecular space. This is the lowest percentage of vital bone reported for the alloplasts in the literature. On the other hand, Brkovic et al. (2008) in a single case report used betatricalcium phosphate with type I collagen (RTR Cone $\mathbb{R}$ ) and reported $62.6 \%$ vital bone, 16.3 non-vital bone and $21.1 \%$ trabecular space. This is the highest percentage of vital bone reported in the alloplast ridge preservation studies. Mangano et al. (2008), in a 20year case report, used dense hydroxyapatite in post-extraction sites to maintain the alveolar height. Based on the results of the study vital bone was $25.4 \%$, non-vital bone $38.1 \%$ and trabecular space represented $41.3 \%$ of the area. In another alloplast study, Crespi et al. (2009) treated 45 sockets out of which 15 were grafted with magnesiumenriched hydroxyapatite (MHA), 15 grafted with calcium sulfate (CS), while the remaining 15 were extraction alone sites. The authors reported $40 \%$ vital bone, $20.2 \%$ non-vital bone and $41.3 \%$ trabecular space in the MHA group whereas the CS group showed $45 \%$ vital bone, $13.9 \%$ non-vital bone and $41.5 \%$ trabecular space. The magnesium HA group had a slower bone turnover rate resulting in less vital bone and more residual graft particles than the calcium sulfate group. McAllister et al. (2010), in a 
3-month study grafted 12 extraction sites with tricalcium phosphate (TCP) mixed with platelet-derived growth factor (PDGF) and reported $21 \%$ vital bone, $24 \%$ non-vital bone and 55\% trabecular space. Toloue et al. (2011), in a 3-month study, studied 13 extraction sockets grafted with calcium sulfate (CS) and reported $31.74 \%$ vital bone, $2.54 \%$ residual graft and 64.98\% trabecular space. In another alloplast study, Gholami et al. (2011) evaluated 14 sites grafted with nanocrystalline HA embedded in a silica gel matrix (Nanobone $\mathbb{R})$ and grafted with a collagen membrane (BioGide $\mathbb{R})$. After 6 months of healing, based on the results of the study, vital bone was $28.6 \%$, residual graft was $13.7 \%$ and trabecular space was $57.7 \%$. Crespi et al. (2011b), in a 4-month split mouth study, observed 15 sites grafted with magnesium-enriched hydroxyapatite (Sintlife, Finceramica). Based on the histologic analysis, the authors reported $36.5 \%$ vital bone, $32.2 \%$ non-vital bone and 33.3\% trabecular space. Checchi et al. (2011) evaluated histologically a total of 10 sockets, 5 of which grafted with a biomimetic hydroxyapatite (T-BHA, SINTlife) and 5 grafted with a nanocrystalline hydroxyapatite (C-NHA, Ostim(B)). All sites were covered with a collagen sponge and examined histologically after 6 months. The nanocrystalline HA had 54\% mature bone, $36 \%$ osteoid tissue. $8 \%$ residual graft and 3\% fibrous tissue. The biomimetic HA group showed $49 \%$ mature bone, $34 \%$ osteoid tissue, $14 \%$ residual graft and $7 \%$ fibrous tissue. Brkovic et al. (2012) evaluated histologically 20 extraction sockets grafted with beta-tricalcium phosphate cones with type I collagen (b-TCP/Clg). 11 of which were left to heal spontaneously and 9 were covered with a barrier membrane (BioGide $\mathbb{R}$ ). After 9 months of healing, the nonmembrane group showed $42.4 \%$ vital bone, $9.7 \%$ non-vital bone and $47.1 \%$ trabecular space, whereas the membrane group showed $45.3 \%$ vital bone, $12.5 \%$ non-vital bone and 
42.1\% trabecular space. Kutkut et al. (2012), in a 3-month non-molar study, evaluated 8 extraction sites grafted with medical-grade calcium sulfate hemihydrate (DentoGen ${ }^{\circledR}$ ) mixed with PRP and 8 sites that received collagen resorbable plug dressing material alone (ACE Surgical Supply®). They reported $66.5 \%$ vital bone for the calcium sulfate/PRP group and $38.3 \%$ vital bone for the resorbable plug alone group.

\section{Graft Healing Characteristics}

According to the literature (Burchardt 1983, Goldberg \& Stevenson 1993), healing and graft maturation varies and is dependent on graft type. Cancellous autografts revascularize earlier than cortical autografts and undergo a process known as creeping substitution, which involves an appositional phase followed by a resorptive phase (Burchardt 1983. Goldberg \& Stevenson 1993). During this process, primitive mesenchymal stem cells differentiate initially to osteoblasts, which line the edges of dead trabeculae and deposit a seam of osteoid that is annealed to, and eventually surrounds, a central core of dead bone (appositional phase). This process of alignment of osteoblasts on existing bone surfaces with the synthesis of osteoid in successive layers to form lamellae, is termed appositional bone formation. Subsequently, the entrapped cores of necrotic bone are gradually resorbed due to osteoclastic activity and a gradual decrease in the overall radiodensity of the cancellous graft is noted (resorptive phase). In time, the cancellous bone graft is completely replaced by viable new bone (Burchardt 1983).

On the other hand, cortical autografts heal by a process known as reverse creeping substitution, where the osteoclastic (resorptive) phase occurs first. leaving an admixture 
of viable and necrotic bone for a prolonged period of time, even years (Burchardt 1983. Goldberg \& Stevenson 1993). The repair process is initiated by osteoclasts, which facilitate resorption of the external cortical surface. Osteoblasts appear only after bone resorption has begun, and the initial deposition of osteoid usually occurs in resorbed areas. Eventually, this leads to a decrease of the mass and radiodensity of the material and concomitantly increases the internal porosity of the graft. Therefore, the strength of graft gradually decreases to the point that cortical grafts lose about one half of their strength in the first 6 months, maintain that strength for another six months, and then slowly regain strength during the second year. Thus, cortical grafts, if examined years after placement, demonstrate an admixture of necrotic and viable bone approximating the strength of normal bone (Burchardt 1983).

Bovine xenografts are considered to be osteoconductive, meaning that they serve as a scaffold in order to facilitate new bone formation (Wallace et al. 2005). Histological evidence has also shown that bovine xenografts tend to resist resorption and remain in place for an extended or an indefinite period of time (Scarano et al. 2004, Vance et al. 2004, Wallace et al. 2005). However, even though foci of vital bone are observed around xenograft particles, it has been also reported that many residual particles become fibrous encapsulated (Vance et al. 2004). Wang et al (2004) utilized a bovine derived xenograft as the outside layer of his layered ("sandwich") approach for ridge augmentation, due to the ability of this graft to resist resorption and act as a scaffold and space occupier. 


\section{Summary of Histologic Findings}

As was stated above, the percentages of vital, non-vital bone and trabecular space vary significantly in the literature and are associated with the different materials as well as with the techniques used for ridge preservation. The following tables (Table 15, Table 16) summarize the histologic results of the ridge preservation studies in the literature. The percentage of vital bone ranged from $1-90 \%$, the percentage of non-vital bone ranged from $0-42 \%$ and the percentage of trabecular space ranged from $33-85 \%$.

Table 15

Comparison of Human Histologic Data on Extraction Alone Studies

\begin{tabular}{|l|c|c|c|}
\hline \multicolumn{1}{|c|}{ Author/Yr } & $\begin{array}{c}\text { Healing } \\
\text { Months }\end{array}$ & \% Vital Bone & $\begin{array}{c}\text { \% Trabecular } \\
\text { Space }\end{array}$ \\
\hline Froum et al. 2002 & $6-8$ & 32 & 68 \\
\hline Iasella et al. 2003 & $4-6$ & 54 & 46 \\
\hline Serino et al. 2003 & 6 & 44 & 56 \\
\hline Barone et al. 2008 & 7 & 26 & 59 \\
\hline Crespi et al. 2009 & 3 & 33 & 65 \\
\hline Pelegrine et al. 2010 & 6 & 43 & 57 \\
\hline Heberer et al. 2011 & 4 & 44 & 56 \\
\hline Crespi et al. 2011b & 4 & 30 & 58 \\
\hline Brownfield et al. 2012 & 3 & 36 & 65 \\
\hline Mean \pm sd & $\mathbf{5 \pm 2}$ & $\mathbf{3 8 \pm 9}$ & $\mathbf{5 9} \pm \mathbf{6}$ \\
\hline
\end{tabular}


Table 16

Comparison of Histologic Data on Ridge Preservation studies

\begin{tabular}{|c|c|c|c|c|c|c|}
\hline Author/Yr & $\begin{array}{c}\text { Graft } \\
\text { Material }\end{array}$ & $\begin{array}{l}\text { Particle } \\
\text { Size }\end{array}$ & $\begin{array}{l}\text { Healing } \\
\text { Months }\end{array}$ & $\begin{array}{l}\text { \% Vital } \\
\text { Bone }\end{array}$ & $\begin{array}{l}\% \text { Non- } \\
\text { Vital } \\
\text { Bone }\end{array}$ & $\begin{array}{c}\% \\
\text { Trabecular } \\
\text { Space }\end{array}$ \\
\hline \multicolumn{7}{|l|}{ Allografts } \\
\hline $\begin{array}{l}\text { Froum et al. } \\
2002\end{array}$ & DFDBA & $\begin{array}{l}250 \text { to } \\
500 \mu \mathrm{m}\end{array}$ & $6-8$ & 34.7 & 13.5 & 51.8 \\
\hline $\begin{array}{l}\text { Iasella et al. } \\
2003\end{array}$ & FDBA & $\begin{array}{l}500-1000 \\
\mu \mathrm{m}\end{array}$ & $4-6$ & 30.1 & 34.7 & 35.2 \\
\hline $\begin{array}{l}\text { Vance et al. } \\
2004\end{array}$ & $\begin{array}{l}\text { DFDBA/putty } \\
\text { (CalMatrix } ₫)\end{array}$ & $\begin{array}{l}500-1000 \\
\mu \mathrm{m}\end{array}$ & 4 & 61.0 & 3.0 & 36.0 \\
\hline $\begin{array}{l}\text { Fotek et al. } \\
2009\end{array}$ & $\begin{array}{l}\text { Canc } \\
\text { Puros/ADM }\end{array}$ & $\begin{array}{l}250-1000 \\
\mu \mathrm{m}\end{array}$ & 4 & 28 & 14 & 58 \\
\hline $\begin{array}{l}\text { Fotek et al. } \\
2009\end{array}$ & $\begin{array}{l}\text { Canc } \\
\text { Puros/PTFE }\end{array}$ & $\begin{array}{l}250-1000 \\
\mu \mathrm{m}\end{array}$ & 4 & 33 & 15 & 52 \\
\hline $\begin{array}{l}\text { Beck et al. } \\
2010\end{array}$ & $\begin{array}{l}\text { Puros } \\
\text { cancellous }\end{array}$ & $\begin{array}{l}250-1000 \\
\mu \mathrm{m}\end{array}$ & 3 & 45.8 & 14.6 & 39.6 \\
\hline $\begin{array}{l}\text { Beck et al. } \\
2010\end{array}$ & $\begin{array}{l}\text { Puros } \\
\text { cancellous }\end{array}$ & $\begin{array}{l}250-1000 \\
\mu \mathrm{m}\end{array}$ & 7 & 45.0 & 13.5 & 41.3 \\
\hline $\begin{array}{l}\text { Engler- } \\
\text { Hamm et al. } \\
2011\end{array}$ & P15, DFDBA & $\begin{array}{l}250-1000 \\
\mu \mathrm{m}\end{array}$ & 6 & 44.0 & 15.5 & 40.5 \\
\hline $\begin{array}{l}\text { Engler- } \\
\text { Hamm et al. } \\
2011\end{array}$ & PI5. DFDBA & $\begin{array}{l}250-1000 \\
\mu \mathrm{m}\end{array}$ & 6 & 52.8 & 6.4 & 40.8 \\
\hline $\begin{array}{l}\text { Toloue } \\
2011\end{array}$ & FDBA & $\begin{array}{l}250-1000 \\
\mu \mathrm{m}\end{array}$ & 3 & 16.7 & 21.4 & 61.6 \\
\hline $\begin{array}{l}\text { Brownfield } \\
\text { et al. } 2012\end{array}$ & Dynablast & NA & 3 & 37.4 & 4.5 & 58.2 \\
\hline $\begin{array}{l}\text { Hoang et al. } \\
2012\end{array}$ & $\begin{array}{l}\text { DBM small } \\
\text { particle }\end{array}$ & $\begin{array}{l}125-710 \\
\mu \mathrm{m}\end{array}$ & 5 & 48.8 & 8.2 & 43.1 \\
\hline $\begin{array}{l}\text { Hoang et al. } \\
2012\end{array}$ & $\begin{array}{l}\text { DBM large } \\
\text { particle }\end{array}$ & $\begin{array}{l}125-710 \\
\mu \mathrm{m}+2-4 \\
\mathrm{~mm}\end{array}$ & 5 & 52.7 & 5.4 & 41.9 \\
\hline $\begin{array}{l}\text { Wood et al. } \\
2012\end{array}$ & FDBA & $\begin{array}{l}250-750 \\
\mu \mathrm{m}\end{array}$ & 5 & 24.6 & 25.4 & 49.9 \\
\hline $\begin{array}{l}\text { Wood et al. } \\
2012\end{array}$ & DFDBA & $\begin{array}{l}250-750 \\
\mu \mathrm{m}\end{array}$ & 5 & 38.4 & 8.9 & 52.7 \\
\hline Mean $\pm s d$ & & & $5 \pm 1$ & $39 \pm 12$ & $14 \pm 9$ & $46 \pm 10$ \\
\hline
\end{tabular}




\begin{tabular}{|c|c|c|c|c|c|c|}
\hline \multicolumn{7}{|l|}{ Xenografts } \\
\hline $\begin{array}{l}\text { Artzi et al. } \\
2000\end{array}$ & BioOss ${ }^{\circledR}$ & $\begin{array}{l}250-1000 \\
\mu \mathrm{m}\end{array}$ & 9 & 46.3 & 30.8 & 42.6 \\
\hline $\begin{array}{l}\text { Zitzmann et } \\
\text { al. } 2001\end{array}$ & BioOss $\mathbb{B}^{\widehat{P}}$ & $\begin{array}{l}250-1000 \\
\mu \mathrm{m}\end{array}$ & 6 & 26.9 & 30.5 & 42.6 \\
\hline $\begin{array}{l}\text { Froum et al. } \\
2004\end{array}$ & $\begin{array}{l}\text { OsteoGraf } \\
\text { R/N300+ } \\
\text { ADM }\end{array}$ & $\begin{array}{l}250-420 \\
\mu \mathrm{m}\end{array}$ & 7 & 42.0 & 13.0 & 45.0 \\
\hline $\begin{array}{l}\text { Froum et al. } \\
2004\end{array}$ & $\begin{array}{l}\text { OsteoGraf } \\
\text { R/N300 } \\
+ \text { ePTFE } \\
\end{array}$ & $\begin{array}{l}250-420 \\
\mu \mathrm{m}\end{array}$ & 7 & 18.0 & 21.0 & 61.0 \\
\hline $\begin{array}{l}\text { Vance et al. } \\
2004\end{array}$ & BioOss $(R)$ & $\begin{array}{l}250-500 \\
\mu \mathrm{m}\end{array}$ & 4 & 26.0 & 16.0 & 54.0 \\
\hline $\begin{array}{l}\text { Barone et } \\
\text { al. } 2008\end{array}$ & $\begin{array}{l}\text { OsteoBiol MP3 } \\
+ \text { OsteoBiol } \\
\text { Evolution } \\
\end{array}$ & $\begin{array}{l}600-1000 \\
\mu \mathrm{m}\end{array}$ & 7 & 35.5 & 29.2 & 36.6 \\
\hline $\begin{array}{l}\text { Cardaropoli } \\
\text { et al. } 2008\end{array}$ & $\begin{array}{l}\text { OsteoBiol } \\
\text { GenOs }+ \\
\text { OsteoBiol } \\
\text { Evolution } \\
\end{array}$ & $\begin{array}{l}250-1000 \\
\mathrm{um}\end{array}$ & 4 & NR & 24.5 & NR \\
\hline $\begin{array}{l}\text { Neiva et al. } \\
2008\end{array}$ & $\begin{array}{l}\text { Putty P-15+ } \\
\text { collaPlug }\end{array}$ & $\begin{array}{l}250-420 \\
u m\end{array}$ & 4 & 29.9 & 6.3 & 65.3 \\
\hline $\begin{array}{l}\text { Nevins et } \\
\text { al. } 2009\end{array}$ & $\begin{array}{l}\text { BioOss } \\
\text { Coll }+ \text { PDGF }\end{array}$ & $\begin{array}{l}250-1000 \\
\mathrm{um}\end{array}$ & 6 & 20.7 & 13.3 & 66.0 \\
\hline $\begin{array}{l}\text { McAllister } \\
\text { et al. } 2010\end{array}$ & PDGF+BioOss & $\begin{array}{l}250-1000 \\
\text { um }\end{array}$ & 3 & 24.0 & 17.0 & 59.0 \\
\hline $\begin{array}{l}\text { Crespi et al. } \\
2011 \mathrm{a}\end{array}$ & $\begin{array}{l}\text { porcine cort/canc } \\
\text { (Tecnoss) }\end{array}$ & $\begin{array}{l}600-1000 \\
\mathrm{um}\end{array}$ & 4 & 39.6 & 34.4 & 26.0 \\
\hline $\begin{array}{l}\text { Crespi et al. } \\
2011 \mathrm{~b}\end{array}$ & porcine cort/canc & $\begin{array}{l}600-1000 \\
\mathrm{um}\end{array}$ & 4 & 38.0 & 36.6 & 25.3 \\
\hline $\begin{array}{l}\text { Gholami et } \\
\text { al. } 2011\end{array}$ & BioOss/BioGide & \begin{tabular}{|l|}
$250-1000$ \\
um
\end{tabular} & 6 & 27.4 & 20.6 & 52.0 \\
\hline $\begin{array}{l}\text { Heberer et } \\
\text { al. } 2011\end{array}$ & BioOss Collagen & $\begin{array}{l}250-1000 \\
\mathrm{um}\end{array}$ & 4 & 25.0 & 15.0 & 60.0 \\
\hline $\begin{array}{l}\text { Nam et al. } \\
2011\end{array}$ & $\begin{array}{l}\text { BioOss/peptide/ } \\
\text { BioGide }\end{array}$ & $\begin{array}{l}250-1000 \\
\mathrm{um}\end{array}$ & 6 & 10.4 & 18.7 & 70.8 \\
\hline $\begin{array}{l}\text { Nam et al. } \\
2011\end{array}$ & BioOss/BioGide & $\begin{array}{l}250-1000 \\
\text { um }\end{array}$ & 6 & 5.3 & 16.4 & 78.3 \\
\hline Mean & & & $5 \pm 2$ & $28 \pm 11$ & $22 \pm 10$ & $51 \pm 17$ \\
\hline
\end{tabular}




\begin{tabular}{|c|c|c|c|c|c|c|}
\hline \multicolumn{7}{|l|}{ Alloplasts } \\
\hline $\begin{array}{l}\text { Froum et al. } \\
2002\end{array}$ & $\begin{array}{l}\text { Bioactive Glass } \\
(\text { BioGran }(\mathbb{B})\end{array}$ & $\begin{array}{l}300-355 \\
\mu \mathrm{m}\end{array}$ & $6-8$ & 59.5 & 5.5 & 35.0 \\
\hline $\begin{array}{l}\text { Froum et al. } \\
2004\end{array}$ & $\begin{array}{l}\text { HA (OsteoGraf } \\
\text { R/LD) + ADM }\end{array}$ & $\begin{array}{l}250-420 \\
\mu \mathrm{m} \\
\end{array}$ & 4 & 35.0 & 4.0 & 62.0 \\
\hline $\begin{array}{l}\text { Froum et al. } \\
2004\end{array}$ & $\begin{array}{l}\text { HA (OsteoGraf } \\
\text { R/LD) + } \\
\text { ePTFE }\end{array}$ & $\begin{array}{l}250.420 \\
\mu \mathrm{m}\end{array}$ & 4 & 28.0 & 12.0 & 61.0 \\
\hline $\begin{array}{l}\text { Luczyszyn } \\
\text { et al. } 2005\end{array}$ & $\begin{array}{l}\text { HA } \\
\text { (Algipore }) \\
+ \text { ADM }\end{array}$ & NA & 6 & 1.0 & 42.0 & 57.0 \\
\hline $\begin{array}{ll}\text { Brkovic et } \\
\text { al.2008 }\end{array}$ & $\begin{array}{l}\text { B-TCP. Type } 1 \\
\text { collagen }\end{array}$ & $\begin{array}{l}500- \\
1000 \mu \mathrm{m}\end{array}$ & 9 & 62.6 & 16.3 & 21.1 \\
\hline $\begin{array}{l}\text { Mangano et } \\
\text { al. } 2008\end{array}$ & dense HA & $\begin{array}{l}1 \text { to } 2 \\
\mu \mathrm{m}\end{array}$ & 240 & 25.4 & 38.1 & 41.3 \\
\hline $\begin{array}{l}\text { Crespi et al. } \\
2009\end{array}$ & $\begin{array}{l}\text { Magnesium } \\
\mathrm{HA}\end{array}$ & $\begin{array}{l}600-900 \\
\mu \mathrm{m}\end{array}$ & 3 & 40 & 20 & 41 \\
\hline $\begin{array}{l}\text { McAllister } \\
\text { et al. } 2010\end{array}$ & PDGF +betaTCP & NA & 3 & 21.0 & 24.0 & 55.0 \\
\hline $\begin{array}{l}\text { Checchi et } \\
\text { al. } 2011\end{array}$ & $\begin{array}{l}\text { biomimetic HA } \\
\text { (Sintl ife) }\end{array}$ & $18 \mathrm{~nm}$ & 6 & 83.0 & 14.0 & 7.0 \\
\hline $\begin{array}{l}\text { Checchi et } \\
\text { al. } 2011\end{array}$ & $\begin{array}{l}\text { nanocrystalline } \\
\text { HA (Ostim) }\end{array}$ & $\begin{array}{l}30-40 \\
\mathrm{~nm} \\
\end{array}$ & 6 & 90.0 & 8.0 & 3.0 \\
\hline $\begin{array}{l}\text { Crespi et al. } \\
2011 \mathrm{~b}\end{array}$ & $\begin{array}{l}\mathrm{Mg}+\mathrm{HA}, \text { no } \\
\mathrm{mem}\end{array}$ & $\begin{array}{l}600-900 \\
\mu \mathrm{m} \\
\end{array}$ & 4 & 36.5 & 32.2 & 33.3 \\
\hline $\begin{array}{l}\text { Gholami et } \\
\text { al. } 2011\end{array}$ & $\begin{array}{l}\text { Nanobone } \\
\text { HA/BioGide }\end{array}$ & $600 \mathrm{um}$ & 6 & 28.6 & 13.7 & 57.7 \\
\hline $\begin{array}{l}\text { Brkovic et } \\
\text { al. } 2012 \\
\end{array}$ & B-TCP cones & NA & 9 & 42.4 & 9.7 & 47.1 \\
\hline $\begin{array}{l}\text { Brkovic et } \\
\text { al. } 2012 \\
\end{array}$ & $\begin{array}{l}\text { B-TCP } \\
\text { cones/BioGide }\end{array}$ & NA & 9 & 45.3 & 12.5 & 42.1 \\
\hline Mean & & & $6 \pm 2$ & $44 \pm 25$ & $16 \pm 11$ & $40 \pm 20$ \\
\hline \multicolumn{7}{|c|}{ Membrane Alone } \\
\hline $\begin{array}{l}\text { Luczyszyn } \\
\text { et al. } 2005 \\
\end{array}$ & ADM & $\mathrm{NA}$ & 6 & 46.0 & 0.0 & 54.0 \\
\hline $\begin{array}{l}\text { Crespi et al. } \\
2011 \mathrm{a}\end{array}$ & $\begin{array}{l}\text { Coll memb ( } \\
\text { Condress) }\end{array}$ & NA & 4 & 29.5 & 0.0 & 57.7 \\
\hline Mean & & & $5 \pm 1$ & $38 \pm 12$ & $\mathbf{0} \pm \mathbf{0}$ & $56 \pm 3$ \\
\hline
\end{tabular}




\begin{tabular}{|l|l|l|c|c|c|c|}
\hline \multicolumn{2}{|l|}{ Collagen Filler Material } \\
\hline $\begin{array}{l}\text { Serino et al. } \\
2003\end{array}$ & $\begin{array}{l}\text { Polylactidel } \\
\text { Polyglycolic } \\
\text { acid sponge } \\
\text { (Fisiograft( })\end{array}$ & NA & 6 & 67.0 & 0.0 & 33.0 \\
\hline $\begin{array}{l}\text { Neiva et al. } \\
2008\end{array}$ & Collaplug & NA & 4 & 36.5 & 0.0 & 62.7 \\
\hline $\begin{array}{l}\text { Crespi et al. } \\
2009\end{array}$ & Calcium sulfate & NA & 3 & 45.0 & 13.9 & 41.5 \\
\hline $\begin{array}{l}\text { Toloue } \\
2011\end{array}$ & CaSO4 & NA & 3 & 31.7 & 2.5 & 65.0 \\
\hline $\begin{array}{l}\text { Kutkut et } \\
\text { al. } 2012\end{array}$ & CaSO4+PRP & NA & 3 & 66.5 & 0.0 & 33.5 \\
\hline $\begin{array}{l}\text { Kutkut et } \\
\text { al. } 2012\end{array}$ & Collagen plug & NA & 3 & 38.3 & 0.0 & 61.7 \\
\hline Mean & & & $\mathbf{4 \pm 1}$ & $\mathbf{4 8 \pm 1 5}$ & $\mathbf{5 \pm 7}$ & $\mathbf{5 0 \pm 1 5}$ \\
\hline
\end{tabular}

$* \mathrm{NR}=$ not reported in article

\begin{tabular}{|l|c|c|c|c|c|}
\hline Summary of Histologic Findings \\
\hline $\begin{array}{l}\text { Graft } \\
\text { Type }\end{array}$ & $\begin{array}{c}\# \\
\text { studies }\end{array}$ & $\begin{array}{c}\text { Healing } \\
\text { Months }\end{array}$ & Vital & Nonvital & Trabecular \\
\hline Autograft & 1 & 6 & 45 & 0 & 55 \\
\hline Allograft & 15 & $5 \pm 1$ & $39 \pm 12$ & $14 \pm 9$ & $46 \pm 10$ \\
\hline Xenograft & 16 & $5 \pm 2$ & $28 \pm 11$ & $22 \pm 10$ & $51 \pm 17$ \\
\hline Alloplast & 14 & $6 \pm 2$ & $44 \pm 25$ & $16 \pm 11$ & $40 \pm 20$ \\
\hline Membrane alone & 2 & $5 \pm 1$ & $38 \pm 12$ & $0 \pm 0$ & $56 \pm 3$ \\
\hline Filler & 6 & $4 \pm 1$ & $48 \pm 15$ & $5 \pm 7$ & $50 \pm 15$ \\
\hline
\end{tabular}




\section{CHAPTER II}

\section{METHODS}

Study design. A total of 24 patients requiring extraction of a non-molar tooth to be replaced by a dental implant participated in this 4-month randomized, controlled, single blinded clinical trial. Twelve positive control patients were randomly selected, using a coin toss, to receive an intrasocket cancellous particulate $500-800 \mu \mathrm{m}$ freezedried bone allograft (RegenerOss ${ }^{\mathrm{TM}}$, Miami Tissue Bank, FL) plus a bioresorbable poly (D, L lactic) acid barrier membrane (Guidor $($ ), while twelve test patients were selected to receive an intrasocket cancellous mineralized particulate $500-800 \mu \mathrm{m}$ freeze-dried bone allograft (RegenerOss ${ }^{\mathrm{TM}}$, Miami Tissue Bank, FL) and a buccal overlay with a particulate $250-1000 \mu \mathrm{m}$ bovine bone xenograft (BioOss $(\mathbb{R}$, Geistlich, New Jersey) plus a bioresorbable poly (D, L) lactic acid barrier (Guidor $\left.{ }^{\circledR}\right)$. Both groups received a full thickness papilla preservation flap on the buccal and lingual/palatal. One operator under the direction of one mentor performed all surgical procedures. The surgeon was trained in the procedures until considered proficient. All measurements were performed by one blinded examiner. The mentor performed the coin toss and verified the measurements taken by the blinded examiner. All patients signed an informed consent approved by the University of Louisville Institutional Review Board in August 2011. The study was conducted between November 2nd, 2011 and July 23rd. 2012 


\section{Figure 1}

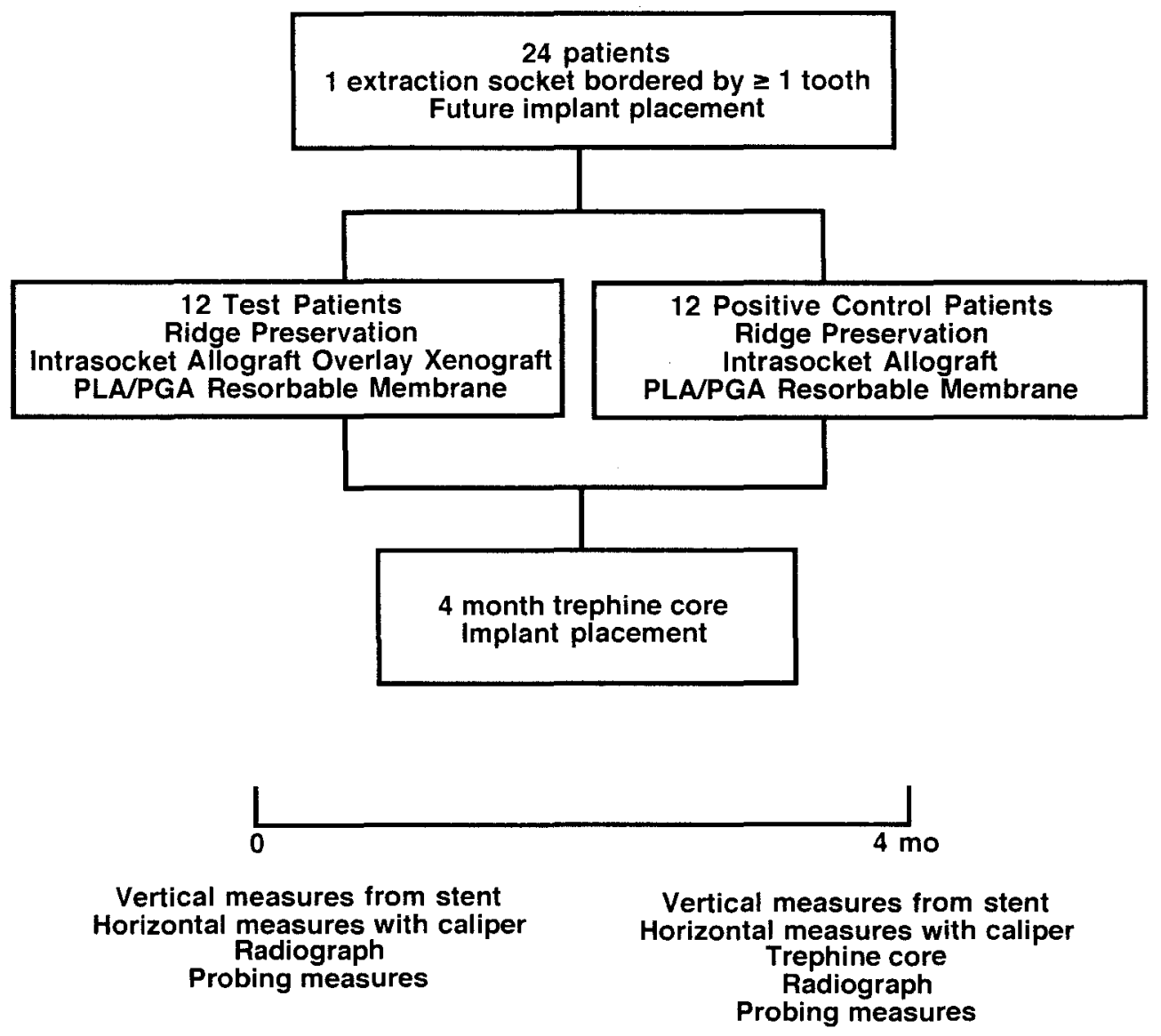

in the Graduate Periodontics clinic. At 4-months post-surgery, a trephine was used to obtain an osseous core from the grafted site prior to the osteotomy for implant placement. 
Trephine cores were sectioned and prepared for histologic analysis using hematoxylin and eosin staining.

Inclusion Criteria. Patients were included in the study if they: 1) had at least one non-molar tooth requiring extraction that will be replaced by a dental implant; 2) had at least one site bordered by at least one tooth; 3) were at least 18 years old; and 4) signed an informed consent approved by the University of Louisville Human Studies Committee.

Exclusion Criteria. Patients were excluded if any of the following were present: 1) Debilitating systemic diseases, or diseases that have a clinically significant effect on the periodontium; 2) Molar teeth; 3) Presence of or history of osteonecrosis of the jaws; 4) Patients who are currently taking IV bisphosphonates or who had IV treatment with bisphosphonates irrespective of the duration; 5) Patients who have been treated with oral bisphosphonates for more than three years; 6) Pregnant women due to the possibility of miscarriage; 7) Patients with an allergy to any material or medication used in the study; 8) Patients in need of prophylactic antibiotics; 9) Patients that have received previous head and neck radiation therapy; 10) Patients that have received chemotherapy in the previous 12 months: 11) Patients on long term NSAID or steroid therapy.

Post-Surgical Exclusion. Any site excluded after surgery was reported. Sites were excluded if there was: 1) loss of graft or barrier material; or 2) unanticipated healing complications that adversely affected treatment results.

Pre-surgical Management. Each patient received a diagnostic work-up including standardized periapical radiographs (Appendix D), study casts, clinical photographs, and a clinical examination to record attachment level, probing depth, recession, and mobility of teeth adjacent to the extracted sites. Customized Triad® occlusal stents were 
fabricated on the study casts to serve as fixed reference guides for the measurements (Appendix F).

Presurgical preparation included detailed oral hygiene instructions. Baseline data was collected just before the surgical phase of the treatment. Baseline data included: 1) Plaque index (Silness \& Löe 1964, Appendix A); 2) Gingival index (Loe 1967, Appendix B); 3) Bleeding on Probing Index (Tagge et al. 1975, Appendix C); 4) Gingival margin levels measured from CEJ to the gingival margin; 5) Keratinized tissue measured from the gingival margin to the mucogingival junction; 6) Clinical attachment level measured from CEJ to the bottom of the clinical periodontal pocket; 7) Clinical tooth mobility measured by using the modified Miller's Index; 8) Horizontal ridge width measured using a digital caliper to the nearest $10^{-2} \mathrm{~mm}$ at the mid point of the alveolar crest and $5 \mathrm{~mm}$ apical to the crest, measured post-extraction and prior to implant placement; 9) Vertical change in the alveolar crest measured post-extraction from the stent to alveolar crest minus re-entry stent to alveolar crest values; 10) Radiographic examination using a customized stent constructed using Triad(R) light cured resin (Appendix F) and a RinnXCP on the patient model (Appendix D) to ensure standardization of the projection; and 11) Clinical photographs.

Surgical Treatment. Patients were anesthetized with $2 \%$ lidocaine containing epinephrine in both 1:100,000 and 1:50,000 concentrations. Full-thickness mucoperiosteal flaps were elevated on the buccal and palatal/ lingual using a papilla preservation technique. The buccal flap extended one tooth mesial and distal in relation to the tooth in need of extraction, preserving the papillae in accordance to Bernimoulin type incisions (Bernimoulin et al. 1975). The palatal/lingual flap used a papilla preservation 
technique confined at the tooth to be extracted. An acrylic stent was used to obtain vertical ridge height measurements relative to the stent.

A digital caliper was utilized to obtain horizontal ridge dimension at the midsocket crest and $5 \mathrm{~mm}$ apical to the crest. Twelve positive control patients were randomly selected, using a coin toss, to receive an intrasocket cancellous particulate $500-800 \mu \mathrm{m}$ freeze-dried bone allograft, while twelve test patients were selected to receive an intrasocket cancellous particulate $500-800 \mu \mathrm{m}$ freeze-dried bone allograft and a buccal overlay with a particulate $250-1000 \mu \mathrm{m}$ bovine bone xenograft (BioOss®). A bioresorbable membrane composed of poly-D, L-lactide, poly-L-lactide, and acetyltributylcitrate (ATBC) a citric acid ester (Guidor ${ }^{\circledR}$, Sunstar, IL) was used to cover the bone grafts in both groups. The flaps were replaced or slightly coronally positioned and sutured with 4-0 Cytoplast PTFE sutures (Osteogenics Biomedical Lubbock, TX). Subjects were given a post-surgical regimen of naproxen sodium (Geneva Pharmaceuticals, Inc. Broomfield, CO), $375 \mathrm{mg}$, every 12 hours for 1 week; doxycycline hyclate $50 \mathrm{mg}$ once daily (Warner Chilcott Inc. Morris Planes, New Jersey) for 2 weeks, and narcotic analgesics as needed. Postoperative care was given at 2,4,8, and 12 weeks. Photographs were taken at each postoperative appointment.

Re-entry Surgery. At 4 months, a standardized radiograph was taken and all baseline measurements were repeated. Patients were anesthetized with $2 \%$ lidocaine containing epinephrine in both 1:100,000 and 1:50,000 concentrations. Full-thickness mucoperiosteal flaps were elevated on the buccal and palatal/lingual using a papilla preservation technique. An acrylic stent was used to obtain vertical ridge height measurements relative to the stent mesially, mid and distally in all buccal, occlusal and 
lingual surfaces. A digital caliper was utilized to obtain horizontal ridge dimension at the mid-buccal crest and $5 \mathrm{~mm}$ apical to the crest.

At 4 months post-surgery, a $2.7 \times 6.0 \mathrm{~mm}$ trephine ( $\mathrm{H} \& \mathrm{H}$ Company Ontario, California) was used to remove a core from the grafted site prior to osteotomy for implant placement. The core was placed into $10 \%$ buffered formalin for histologic preservation. An osteotomy site was prepared and an endosseous dental implant was placed. The flaps were replaced and sutured with 4-0 silk or 4-0 Cytoplast ${ }^{\circledR}$ PTFE sutures. Patients were again given Naproxen $375 \mathrm{mg}$, Doxycycline hyclate $50 \mathrm{mg}$ and analgesics as needed.

Histology. Trephine cores $(2.7 \times 6 \mathrm{~mm})$ were decalcified and step serial sections were taken from each longitudinally sectioned core. The sections were stained with hematoxylin and eosin. Ten slides per patient were prepared with at least 4 sections per slide. All slides were evaluated and 6 of 10 representative slides were counted. The mean percentage of vital and non-vital bone and trabecular space was calculated for each patient by using an American Optical microscope at $150 \mathrm{X}$ with a $10 \mathrm{X} 10$ ocular grid.

Statistical Analysis. Means and standard deviations were calculated for all parameters. A paired t-test was used to evaluate the statistical significance of the differences between initial and final data. An unpaired t-test was used to evaluate statistical differences between the test and control groups. The sample size of 12 per group gave $83 \%$ statistical power to detect a difference of $1 \mathrm{~mm}$ between groups. Power calculations were based on data from previous studies. 


\section{CHAPTER III}

\section{RESULTS}

A total of 8 females and 4 males with a mean age of $52 \pm 16$, ranging from 26 to 77 , were enrolled in the Intrasocket group while 5 females and 6 males with a mean age of $58 \pm 12$, ranging from 38 to 71 , were enrolled in the Overlay group. All sites were bordered by at least one tooth mesially or distally. All 24 patients completed the study, however, 1 patient was excluded from clinical data analysis. This patient had a buccal wall missing and the amount ridge width gain was large. This represented an outlier value that skewed the data. The Intrasocket group consisted of 1 maxillary incisor, 2 maxillary canines, 8 maxillary premolars, and 1 mandibular premolar. The Overlay group consisted of 4 maxillary incisors, 1 maxillary canine, and 6 maxillary premolars. There were 2 smokers enrolled in the Intrasocket group 2 smokers enrolled in the Overlay group. Data from this study were derived from 23 patients all treated by one operator (EP), supervised by one mentor (HG), and evaluated by one examiner (TP).

Clinical Indices. Plaque index, gingival index and bleeding on probing had low initial values for both groups and the majority of values only changed slightly by the 4 month reentry (Table 17). There were no significant differences between the control and the test group $(\mathrm{p}>0.05)$.

Horizontal Ridge Width Changes. The Intrasocket group presented with a mean crestal width of $8.7 \pm 1.0 \mathrm{~mm}$, which decreased to $7.1 \pm 1.5 \mathrm{~mm}$ at the 4 month 
reentry for a mean loss of $1.6 \pm 0.8 \mathrm{~mm}(\mathrm{p}<0.05$, Table 18). For the Overlay group the mean initial width at the crest was $8.4 \pm 1.4 \mathrm{~mm}$, which decreased to $8.1 \pm 1.4 \mathrm{~mm}$ for a mean loss of $0.3 \pm 0.9 \mathrm{~mm}(\mathrm{p}>0.05)$. The Intrasocket group had a mean initial width 5 $\mathrm{mm}$ apical to the crest of $9.1 \pm 0.9 \mathrm{~mm}$, which decreased to $8.4 \pm 0.9 \mathrm{~mm}$ at 4 months for a mean loss of $0.8 \pm 0.5 \mathrm{~mm}(\mathrm{p}<0.05)$. The Overlay group had a mean initial width 5 $\mathrm{mm}$ apical to the crest of $8.6 \pm 1.9 \mathrm{~mm}$, which increased to $9.1 \pm 2.0 \mathrm{~mm}$ for a mean gain of $0.5 \pm 0.6 \mathrm{~mm}(\mathrm{p}<0.05)$. The differences between the control and test group regarding horizontal ridge width change were significant both at the level of the crest and at $5 \mathrm{~mm}$ apically. $(p<0.05)$.

Vertical mid-Buccal Ridge Height Changes. The Intrasocket group had a mean mid-buccal ridge height gain of $0.5 \pm 2.9 \mathrm{~mm}(p>0.05$, Table 19), while the Overlay group had a mean gain $0.3 \pm 2.6 \mathrm{~mm}(\mathrm{p}>0.05)$. There were no statistically significant differences between the Intrasocket and Overlay groups for the mid-buccal change ( $p>$ $0.05)$.

Vertical mid-Lingual Ridge Height Changes. Mid-lingual ridge height in the Intrasocket group had a mean loss of $0.4 \pm 0.6 \mathrm{~mm}(\mathrm{p}>0.05$, Table 19), while the Overlay group had a mean loss of $0.5 \pm 0.7 \mathrm{~mm}(\mathrm{p}<0.05)$. There were no statistically significant differences between groups $(p>0.05)$.

Vertical Mesial Ridge Height Changes. Vertical mesial ridge height for the Intrasocket group had a mean loss of $0.5 \pm 0.4 \mathrm{~mm}(\mathrm{p}<0.05$, Table 19), while the Overlay group had a mean loss of $0.6 \pm 0.4 \mathrm{~mm}(\mathrm{p}<0.05)$. There were no statistically significance differences between groups $(\mathrm{p}>0.05)$. 
Vertical Distal Ridge Height Changes. Vertical distal ridge height for the Intrasocket group showed a mean loss of $0.8 \pm 0.3 \mathrm{~mm}(\mathrm{p}<0.05$, Table 19), while the Overlay group had a mean loss of $0.4 \pm 0.4 \mathrm{~mm}(\mathrm{p}<0.05)$. The difference between the groups was statistically significant $(p>0.05)$.

CEJ to Osseous Crest Changes. CEJ to Osseous crest change for the Intrasocket group mesially showed a mean loss of $0.3 \pm 0.3 \mathrm{~mm}(\mathrm{p}<0.05$, Table 20$)$, while the Overlay group had a mean loss of $0.5 \pm 0.4 \mathrm{~mm}(\mathrm{p}<0.05)$. CEJ to Osseous crest change for the Intrasocket group distally showed a mean loss of $0.5 \pm 0.7 \mathrm{~mm}(p<0.05$, Table $20)$, while the Overlay group had a mean loss of $0.3 \pm 0.5 \mathrm{~mm}(\mathrm{p}>0.05)$. There were no significant differences between groups.

Histologic evaluation. Intrasocket group sites healed with $35 \pm 16 \%$ vital bone, $21 \pm 13 \%$ non-vital bone and $44 \pm 9 \%$ trabecular space, while Overlay group sites healed with $40 \pm 16 \%$ vital bone, $17 \pm 11 \%$ non-vital bone, and $43 \pm 12 \%$ trabecular space. For vital bone, non-vital bone and trabecular space there were no statistically significant differences between the Intrasocket and Overlay groups ( $p>0.05$, Table 21). Histologic results from previous $\mathrm{U}$ of $\mathrm{L}$ ridge preservation studies (Table 22) and ridge augmentation studies (Table 23) are summarized to allow comparison of different grafting materials. 
Table 17

\section{Clinical Indices for Intrasocket and Overlay Sites}

Mean $\pm s d$ in index units

\begin{tabular}{|c|c|c|c|c|}
\hline & & Initial & Final & Change \\
\hline Plaque & Intrasocket & $0.1 \pm 0.1$ & $0.1 \pm 0.1$ & $0.0 \pm 0.1$ \\
\hline Index & Overlay & $0.1 \pm 0.1$ & $0.1 \pm 0.1$ & $0.0 \pm 0.1$ \\
\hline Gingival & Intrasocket & $0.1 \pm 0.1$ & $0.1 \pm 0.1$ & $0.0 \pm 0.1$ \\
\hline Index & Overlay & $0.2 \pm 0.2$ & $0.2 \pm 0.2$ & $0.0 \pm 0.2$ \\
\hline $\begin{array}{l}\text { Bleeding } \\
\text { on }\end{array}$ & Intrasocket & $0.1 \pm 0.1$ & $0.1 \pm 0.1$ & $0.0 \pm 0.1$ \\
\hline Probing & Overlay & $0.1 \pm 0.1$ & $0.2 \pm 0.1$ & $0.1 \pm 0.1$ \\
\hline
\end{tabular}


Table 18

Horizontal Ridge Width for Intrasocket and Overlay Sites

Mean \pm sd in $\mathbf{m m}$

\begin{tabular}{|c|c|c|c|c|c|}
\hline & Initial & Final & Change & $\%$ Change & Range \\
\hline & Initial & Final & Change & & Range \\
\hline Intrasocket at Crest & $8.7 \pm 1.0$ & $7.1 \pm 1.5$ & $-1.6 \pm 0.8$ & $-19 \pm 11 *$ & $-3 .+10-0.5$ \\
\hline Overlay at Crest & $8.4 \pm 1.4$ & $8.1 \pm 1.4$ & $-0.3 \pm 0.9$ & $-3 \pm 10+$ & 2.0 to 0.9 \\
\hline Intrasocket at $5 \mathrm{~mm}$ & $9.1 \pm 0.9$ & $8.4 \pm 0.9$ & $-0.8 \pm 0.5$ & $-8 \pm 5^{*}$ & -1.8 to 0.0 \\
\hline Overlay at $5 \mathrm{~mm}$ & $8.6 \pm 1.9$ & $9.1 \pm 2.0$ & $0.5 \pm 0.6$ & $7 \pm 8 *+$ & -0.8101 .5 \\
\hline
\end{tabular}


Table 19

Vertical Ridge Height Change for Intrasocket and Overlay Sites

Mean $\pm s d$ in $\mathbf{m m}$

\begin{tabular}{|lcccc|}
\hline Location & Intrasocket & Overlay & Intrasocket & Overlay \\
\hline & Mean Change \pm sd in mm & \multicolumn{2}{c|}{ Range in mm } \\
\hline Mid-Buccal & $0.5 \pm 2.9$ & $0.3 \pm 2.6$ & -2.0 to 8.0 & -3.0 to 5.0 \\
Mid-Lingual & $-0.4 \pm 0.6$ & $-0.5 \pm 0.7^{*}$ & -1.5 to 0.5 & -1.5 to 0.5 \\
Mesial & $-0.5 \pm 0.4^{*}$ & $-0.6 \pm 0.4^{*}$ & -1.2 to 0.0 & -1.1 to 0.0 \\
Distal & $-0.8 \pm 0.3^{*}$ & $-0.4 \pm 0.4^{*}+$ & -1.3 to -0.1 & -1.0 to 0.0 \\
\hline
\end{tabular}

$*=\mathrm{p}<0.05$ between initial and 4 -month values

$+=p<0.05$ between overlay and intrasocket groups 
Table 20

CEJ to Osseous Crest Change at Adjacent Teeth

Mean $\pm \mathrm{sd}$ in $\mathbf{m m}$

\begin{tabular}{|lcccc|}
\hline & $\mathbf{n}$ & Initial & Final & Change \\
\hline Intrasocket & 11 & $3.2 \pm 0.7$ & $3.5 \pm 0.8$ & $-0.3 \pm 0.3^{*}$ \\
Mesial & 9 & $3.0 \pm 0.9$ & $3.6 \pm 1.2$ & $-0.5 \pm 0.7^{*}$ \\
Distal & 11 & $3.3 \pm 1.1$ & $3.8 \pm 1.2$ & $-0.5 \pm 0.4^{*}$ \\
\hline Overlay & 11 & $4.0 \pm 1.2$ & $4.3 \pm 1.2$ & $-0.3 \pm 0.5$ \\
Mesial & & & & \\
Distal & & & & \\
\hline
\end{tabular}

$*=p<0.05$ between initial and 4 -month values 
Table 21

Histologic Data at Implant Placement for Intrasocket and Overlay Sites

Mean $\pm \mathrm{sd}$

\begin{tabular}{|lllccc|}
\hline Group & Time & n & \% Vital & \% Non-vital & \% Trabecular \\
\hline Intrasocket & + month & 12 & $35 \pm 16$ & $21 \pm 13$ & $4+ \pm$ \\
\hline Overlay & + month & 11 & $40 \pm 16$ & $17 \pm 11$ & $43 \pm 12$ \\
\hline
\end{tabular}


Table 22

Comparison of Histologic Data from U of L Ridge Preservation Studies

Mean \pm sd

\begin{tabular}{|c|c|c|c|c|c|c|}
\hline Study & Treatment & $\begin{array}{l}\text { Time } \\
\text { in mo } \\
\end{array}$ & $\mathbf{n}$ & $\begin{array}{c}\% \\
\text { Vital } \\
\end{array}$ & $\begin{array}{c}\% \\
\text { Non-vital }\end{array}$ & $\begin{array}{c}\% \\
\text { Trabecular } \\
\end{array}$ \\
\hline $\begin{array}{l}\text { Iasella et al. } \\
2003\end{array}$ & $\begin{array}{l}\text { FDBA/BioMend } \\
\text { Extraction Alone }\end{array}$ & $\begin{array}{l}4-6 \\
4-6 \\
\end{array}$ & $\begin{array}{l}12 \\
10 \\
\end{array}$ & $\begin{array}{l}28 \pm 14 \\
54 \pm 12 \\
\end{array}$ & $\begin{array}{c}37 \pm 18 \\
* \\
\end{array}$ & $\begin{array}{l}35 \pm 10 \\
H \pm 12 \\
\end{array}$ \\
\hline $\begin{array}{l}\text { Vance et al. } \\
2004\end{array}$ & $\begin{array}{l}\text { Calmatrix } \\
\text { BioOss }\end{array}$ & $\begin{array}{r}4 \mathrm{mo} \\
4 \mathrm{mo} \\
\end{array}$ & $\begin{array}{l}12 \\
12 \\
\end{array}$ & $\begin{array}{c}61 \pm 9 \\
26 \pm 20 \\
\end{array}$ & $\begin{array}{c}3 \pm 3 \\
16 \pm 7 \\
\end{array}$ & $\begin{array}{r}36 \pm 8 \\
59 \pm 16 \\
\end{array}$ \\
\hline $\begin{array}{l}\text { Adams et al. } \\
2005\end{array}$ & $\begin{array}{l}\text { Intra } \\
\text { Cort/ADM } \\
\text { Overlay }\end{array}$ & $\begin{array}{l}+\mathrm{mo} \\
+\mathrm{mo} \\
\end{array}$ & $\begin{array}{l}13 \\
13 \\
\end{array}$ & $\begin{array}{l}37 \pm 15 \\
36 \pm 18 \\
\end{array}$ & $\begin{array}{l}31 \pm 15 \\
26 \pm 17 \\
\end{array}$ & $\begin{array}{l}32 \pm 5 \\
38 \pm 10 \\
\end{array}$ \\
\hline $\begin{array}{l}\text { Siu et al. } \\
2007 \\
\end{array}$ & $\begin{array}{l}\text { Hlap } \\
\text { GMP/MnOs } \\
\text { Flapless } \\
\end{array}$ & $\begin{array}{r}4 \mathrm{mo} \\
4 \mathrm{mo} \\
\end{array}$ & $\begin{array}{l}12 \\
12 \\
\end{array}$ & $\begin{array}{l}35 \pm 15 \\
4 \pm 10\end{array}$ & $\begin{array}{l}19 \pm 12 \\
17 \pm 13 \\
\end{array}$ & $\begin{array}{l}46 \pm 17 \\
39 \pm 9 \\
\end{array}$ \\
\hline $\begin{array}{l}\text { Witonsky et al. } \\
2009\end{array}$ & $\begin{array}{l}\text { CancBioOss/CP } \\
\text { Cort/hdPTFE }\end{array}$ & $\begin{array}{l}4 \mathrm{mo} \\
4 \mathrm{mo} \\
\end{array}$ & $\begin{array}{l}12 \\
12\end{array}$ & $\begin{array}{l}28 \pm 20 \\
35 \pm 21\end{array}$ & $\begin{array}{l}37 \pm 16 \\
31 \pm 22 \\
\end{array}$ & $\begin{array}{l}35 \pm 13 \\
34 \pm 10\end{array}$ \\
\hline $\begin{array}{l}\text { Sams et al. } \\
2010\end{array}$ & $\begin{array}{l}\text { Cancellous } \\
\text { Cortical }\end{array}$ & $\begin{array}{l}4 \mathrm{mo} \\
+\mathrm{mo} \\
\end{array}$ & $\begin{array}{l}12 \\
12 \\
\end{array}$ & $\begin{array}{l}37 \pm 13+ \\
19 \pm 10\end{array}$ & $\begin{array}{l}21 \pm 1.3+ \\
38 \pm 11 \\
\end{array}$ & $\begin{array}{l}43 \pm 6 \\
43 \pm 11 \\
\end{array}$ \\
\hline $\begin{array}{l}\text { Kotevska et al. } \\
2011\end{array}$ & $\begin{array}{l}\text { Cancellous } \\
\text { Demineralized }\end{array}$ & $\begin{array}{l}4 \mathrm{mo} \\
4 \mathrm{mo} \\
\end{array}$ & 12 & $\begin{array}{l}38 \pm 14 \\
40 \pm 13 \\
\end{array}$ & $\begin{array}{l}29 \pm 14 \\
21 \pm 14 \\
\end{array}$ & $\begin{array}{l}32 \pm 10 \\
39 \pm 11 \\
\end{array}$ \\
\hline $\begin{array}{l}\text { Poulias et al. } \\
2012\end{array}$ & $\begin{array}{l}\text { Intrasocket } \\
\text { Canc/BioOss } \\
\text { Overlay }\end{array}$ & $\begin{array}{l}4 \text { mo } \\
+ \text { mo }\end{array}$ & 12 & $\begin{array}{l}35 \pm 16 \\
40 \pm 16 \\
\end{array}$ & $\begin{array}{l}21 \pm 1.3 \\
17 \pm 11 \\
\end{array}$ & $H \pm 9$ \\
\hline
\end{tabular}


Table 23

Comparison of Histologic Data from U of L Ridge Augmentation Studies

Mean \pm sd

\begin{tabular}{|c|c|c|c|c|c|c|}
\hline Study & Treatment & $\begin{array}{l}\text { Time } \\
\text { in mo }\end{array}$ & $\mathbf{n}$ & $\begin{array}{c}\% \\
\text { Vital }\end{array}$ & $\begin{array}{c}\% \\
\text { Non-vital }\end{array}$ & $\begin{array}{c}\% \\
\text { Trabecular }\end{array}$ \\
\hline \multirow{3}{*}{$\begin{array}{l}\text { Cordini et al. } \\
2005\end{array}$} & Canc Block & 4 & 8 & $33 \pm 25$ & $24 \pm 18$ & $42 \pm 12$ \\
\hline & ADM membrane & & & & & \\
\hline & DBM (Graf Flex) & 4 & 2 & $56 \pm 9$ & $5 \pm 5$ & $38 \pm 3$ \\
\hline \multirow{3}{*}{$\begin{array}{l}\text { Lahey et al. } \\
2005\end{array}$} & Canc Block & 4 & 11 & $51 \pm 18$ & $11 \pm 9$ & $39 \pm 14$ \\
\hline & ADM membrane & & & & & \\
\hline & Particulate Cort & + & 10 & $58 \pm 12$ & $11 \pm 7$ & $31 \pm 7$ \\
\hline \multirow{3}{*}{$\begin{array}{l}\text { Clagett et al. } \\
2006\end{array}$} & Canc Block & 4 & 11 & $56 \pm 12$ & $8 \pm 6$ & $36 \pm 10$ \\
\hline & ADM membrane & & & & & \\
\hline & Paste (Regen) & + & 10 & $5.3 \pm 10$ & $8 \pm 8$ & $36 \pm 13$ \\
\hline \multirow{3}{*}{$\begin{array}{l}\text { Dib et al. } \\
2007\end{array}$} & Canc Block & 4 & 11 & $57 \pm 10$ & $11 \pm 10$ & $32 \pm 10$ \\
\hline & ADM membrane & & & & & \\
\hline & GMP/MnOss & + & 12 & $60 \pm 13$ & $7 \pm 9$ & $33 \pm 11$ \\
\hline \multirow{3}{*}{$\begin{array}{l}\text { Ratliff et al. } \\
2009\end{array}$} & Cortical & 4 & 11 & $47 \pm 11$ & $4 \pm 4$ & $49 \pm 9$ \\
\hline & ADM membrane & & & & & \\
\hline & Cancellous & + & 11 & $58 \pm 11+$ & $5 \pm 6$ & $37 \pm 8$ \\
\hline
\end{tabular}




\section{CHAPTER IV}

\section{DISCUSSION}

In this 4-month randomized, controlled, blinded clinical study of ridge preservation in humans two different grafting techniques were compared. The positive control group received an intrasocket particulate cancellous allograft (Intrasocket group) while the test group received an intrasocket particulate cancellous allograft plus a buccal overlay with a particulate bovine xenograft (Overlay group). A bioresorbable poly (D, L) lactic acid barrier membrane (Guidor ${ }^{\circledR}$ ) was used for both groups. In terms of clinical ridge dimensions there was a statistically significant difference between groups both at the alveolar crest level and more apically at the $5 \mathrm{~mm}$ level $(\mathrm{p}<0.05)$. Histologic evaluation of trephine cores revealed no significant differences between the groups for vital bone, non-vital bone, or trabecular space $(p>0.05)$.

The horizontal clinical ridge dimension results in this study are within the range reported in previous studies, which varied from -3.5 to $+1.1 \mathrm{~mm}$ (Table 8). The mean horizontal loss reported from those studies was $1.5 \pm 0.9 \mathrm{~mm}$. In this study, the Intrasocket group showed a mean loss $1.6 \pm 0.8 \mathrm{~mm}$ at the crest while the Overlay group lost $0.3 \pm 0.9 \mathrm{~mm}(\mathrm{p}<0.05)$. Five millimeters apical to the crest, the intrasocket group showed a loss of $0.8 \pm 0.5 \mathrm{~mm}$ while the Overlay group gained $0.5 \pm 0.6 \mathrm{~mm}(\mathrm{p}<0.05)$. 
The Overlay group showed significantly greater ridge dimensions at both measurement points.

Previous reports of extraction alone showed a mean horizontal loss of $3.7 \pm 1.0$ $\mathrm{mm}$ or $45 \pm 16 \%$ of the initial ridge width (Table 6). In contrast, previous ridge preservation studies show a mean percent horizontal loss of $18 \pm 11 \%$ (Table 9). Thus, based on previous literature, the use of a ridge preservation procedure appears to be beneficial in terms of reducing the loss of ridge width. In this study the Intrasocket group lost $19 \%$ of the crestal width while the Overlay group lost only $3 \%(p<0.05)$. Thus the use of a buccal overlay graft tended to preserve original ridge dimensions while there was some loss of ridge width when the intrasocket graft alone was used.

Frequency data reveals that 5 patients in the Overlay group lost crestal ridge dimension while 7 gained. The change ranged from a loss of $2.0 \mathrm{~mm}$ to a gain of 0.9 $\mathrm{mm}$. So not every patient gained. This is in contrast to the Intrasocket group where all patients lost crestal ridge width and the loss ranged from 3.4 to $0.5 \mathrm{~mm}$. For the Overlay group five millimeters apical to the crest 9 patients gained ridge width while only 2 lost. The change ranged from -0.8 to $+1.5 \mathrm{~mm}$. In contrast, for the Intrasocket group 11 of 12 patients lost ridge width and none gained. The change ranged from -1.8 to $0.0 \mathrm{~mm}$. This frequency data indicates that crestal ridge width is the most difficult to maintain while more apical areas will most likely gain when an Overlay graft is used.

Simon et al. (2000) also studied ridge preservation using an overlay graft and showed a mean gain of $1.1 \mathrm{~mm}$. The results of this study are in general agreement with their findings of positive changes resulting from an Overlay graft. Their overlay graft technique differed in that they covered both the buccal and palatal/lingual. Another 
difference was in measurement technique where they measured $3 \mathrm{~mm}$ apical to the crest. These two factors may account for the small differences in study outcomes.

In this study, the vertical ridge dimension showed a mean mid-buccal change of +0.5 for the Intrasocket group and $+0.3 \mathrm{~mm}$ for the Overlay group $(\mathrm{p}>0.05)$. Previous studies have shown a mean change of $-0.1 \mathrm{~mm}$ with a range of -2.0 to $+1.3 \mathrm{~mm}$. Thus mean vertical change found in this study is comparable to previous reports.

Histologic results from this study showed $35 \pm 16 \%$ vital bone, $21 \pm 13 \%$ nonvital bone and $44 \pm 9 \%$ trabecular space for the Intrasocket group. The Overlay group had 40 $\pm 16 \%$ vital, $17 \pm 11 \%$ non-vital and $43 \pm 12 \%$ trabecular space. Both treatments were effective in producing similar amounts of vital bone and there were no. statistically significant differences between groups. The buccal overlay xenograft did not seem to alter the healing of the intrasocket cancellous allograft. In fact, the cancellous allograft healed with a relatively high percentage of vital bone in the socket site where the implant was ultimately placed. Cancellous autografts heal by a process known as creeping substitution whereby the osteoblastic phase occurs first and produces appositional bone growth, which is then followed by a resorptive phase (Burchardt 1983, Goldberg and Stevenson 1993). This results in more rapid graft resorption and a greater amount of vital bone formation. The allograft used in this study followed the same healing pattern as previously reported for autografts (Burchardt 1983, Goldberg and Stevenson 1993). In contrast, cortical bone heals by a process known as reverse creeping substitution where the osteoclastic phase occurs first. This leaves a mixture of vital and nonvital bone that may remain for an extended period. The bovine xenograft used in this study was selected since it tends to resist resorption, becomes fibrous encapsulated, and remains in place for 
an extended or indefinite period (Vance et al. 2004). Wang et al. (2004) utilized this characteristic of bovine xenograft in a layered grafting technique where the primary purpose of the xenograft layer was to resist graft resorption.

The overlay graft technique used in this study prevented ridge resorption to a statistically significant degree when compared to the intrasocket graft alone. Thus there was only $3 \%$ crestal ridge resorption when the xenograft overlay was used vs. $19 \%$ when it was not utilized. Histologically both techniques produced similar results and produced a substantial amount of vital bone in the socket area, which was the ultimate site of implant placement. Both techniques produced an acceptable clinical and histologic result and are appropriate for use in ridge preservation procedures. 


\section{CHAPTER V CONCLUSIONS}

Within the limits of this study design and sample size it may be concluded that:

1) Mean crestal and $5 \mathrm{~mm}$ apical ridge width was significantly greater for the Overlay group $(\mathrm{p}<0.05)$ indicating that the bovine overlay xenograft contributed to improved final ridge dimensions when compared to an intrasocket allograft alone.

2) There were no statistically significant differences in mid-buccal ridge height between groups $(p>0.05)$.

3) Histomorphometric analysis revealed that there were no significant differences in the amount of vital bone, non-vital bone or trabecular space between groups ( $p>$ $0.05)$.

4) The poly (D, L lactic) acid membrane was left exposed over the socket opening and the exposed portion was usually resorbed by 8 weeks post-op and resulted in normal graft healing. 


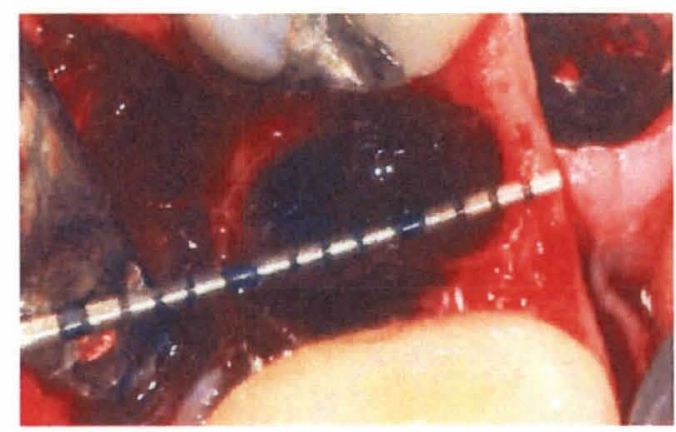

Figure 2. a) Case 1, Pre-op

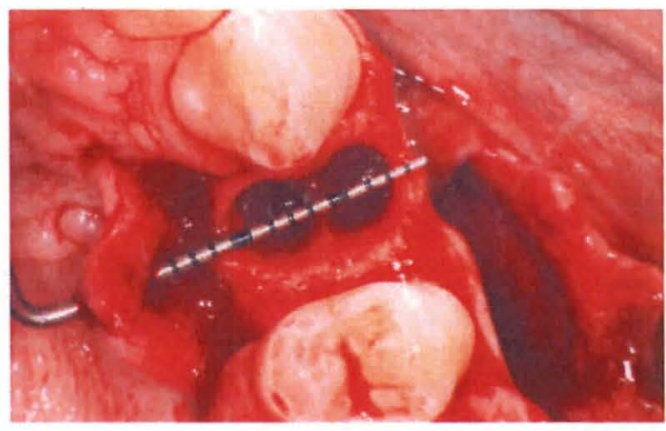

Figure 3. a) Case 2, Pre-op

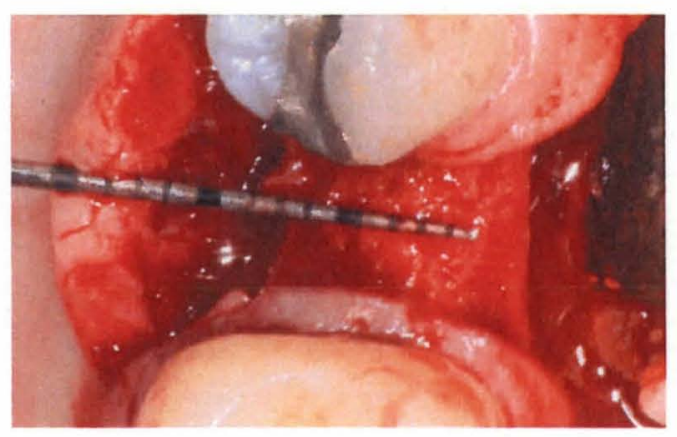

b) 4-month re-entry

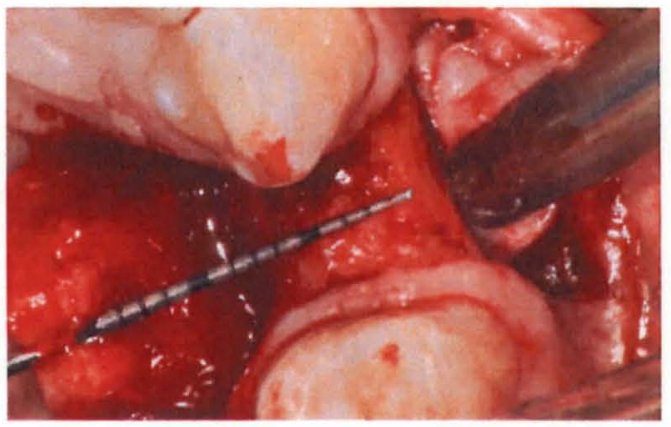

b) 4-month re-entry.

Intrasocket Group 

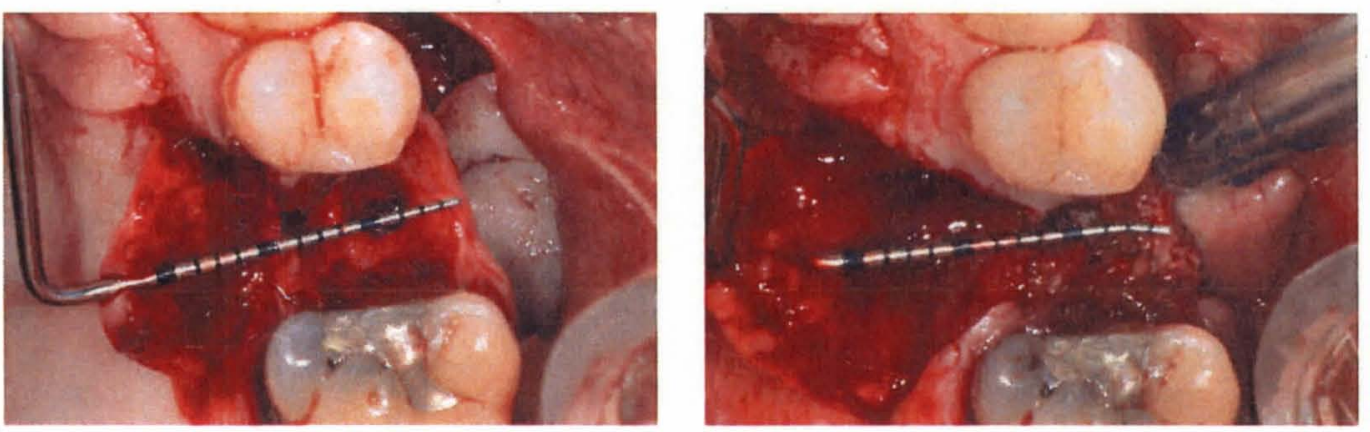

Figure 4. a) Case 3 Pre-op

b) 4-month re-entry
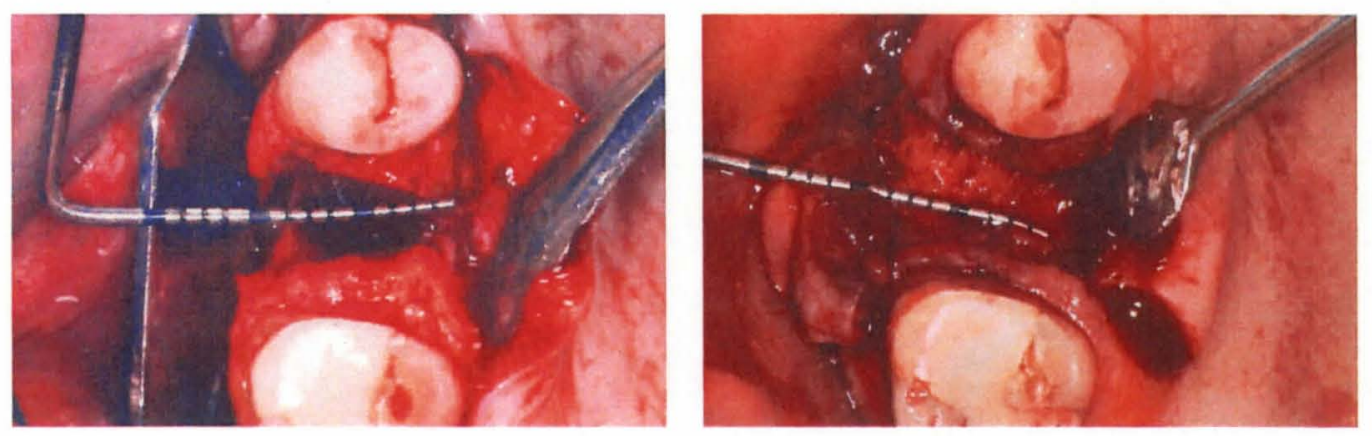

Figure 5. a) Case 4 Pre-op

b) 4-month re-entry

\section{Overlay Group}




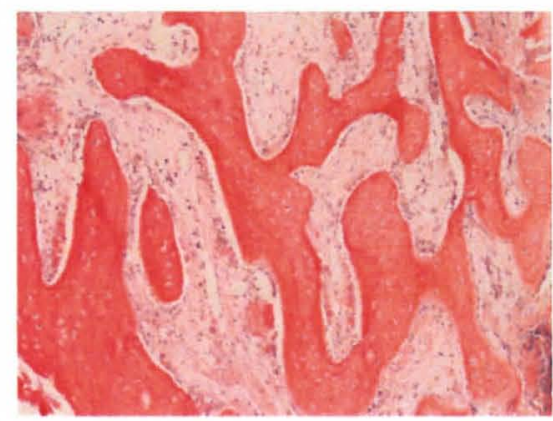

Figure 6. a) Vital bone

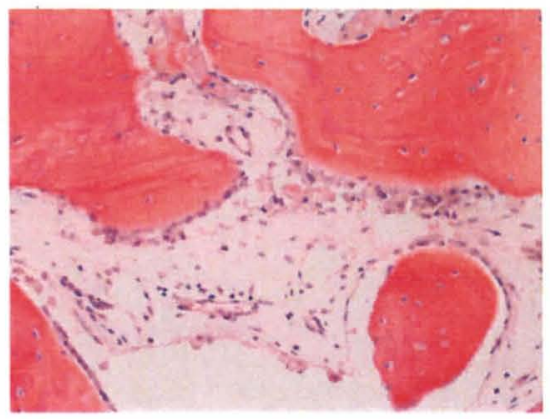

Figure 7. a) Osteoblasts lining vital bone

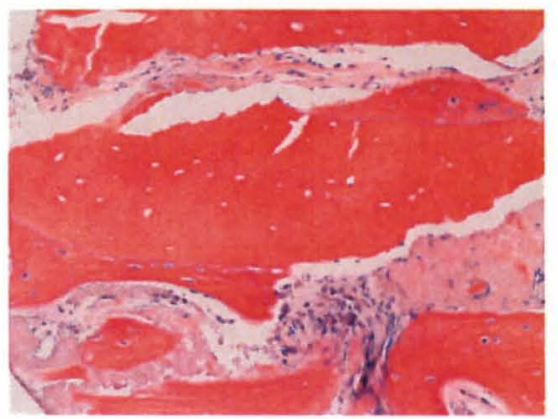

b) Appositional bone growth

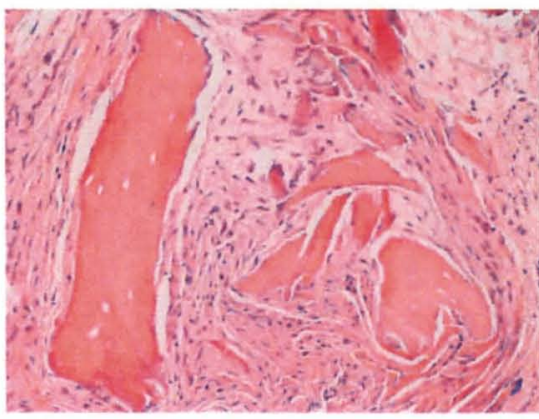

b) Fibrous encapsulation

\section{Representative Histologic Sections}




\section{REFERENCES}

Adams DA. Ridge preservation comparing an intrasocket FDBA allograft alone to a combined intra-and extra-socket FDBA allograft both covered with acellular dermal matrix membrane. |Thesis|. Louisville, Kentucky. University of Louisville. 2005.

Amler MH, Johnson PL, Salman I. Histologic and histochemical investigation of human alveolar socket healing in undisturbed extraction wounds. J Am Dent Assoc 1960;6:132144.

Araújo M, Linder E, Wennström J, Lindhe J. The influence of Bio-Oss Collagen on healing of an extraction socket: an experimental study in the dog. Int $\mathbf{J}$ Periodontics Restorative Dent 2008;28 (2):123-135.

Araujo MG, Lindhe J. Dimensional ridge alterations following tooth extraction. An experimental study in the dog. J Clin Periodontol 2005;32(2):212-218.

Araújo MG, Lindhe J. Ridge alterations following tooth extraction with and without flap elevation: an experimental study in the dog. Clin Oral Implants Res 2009:20(6):545-549.

Araujo MG, Lindhe J. Socket grafting with the use of autologous bone: an experimental study in the dog Clinical Oral Implant Research 2011;22:9-13.

Araujo MG, Sukekava F, Wennstrom JL, Lindhe J. Ridge alterations following implant placement in fresh extraction sockets: an experimental study in the dog. J Clin Periodontol 2005;32(6):645-652.

Artzi Z, Tal H, Dayan D. Porous bovine bone mineral in healing of human extraction sockets: Part 1: histomorphometric evaluations at 9 months. J Periodontol 2000;71(6): 1015-1023.

Ash MM. Wheeler's dental anatomy, physiology, and occlusion (6th edition), WB Saunders Co., Philadelphia. Book 1984.

Ashman A. Postextraction ridge preservation using a synthetic alloplast. Implant Dent 2000;9(2): 168-176. 
Barone A, Aldini NN, Fini M, Giardino R, Guirado JL, Covani U. Xenograft versus extraction alone for ridge preservation after tooth removal: $A$ clinical and histomorphometric study. J Periodontol 2008;79:1370-1377.

Beck TM, Mealey BL. Histologic analysis of healing after tooth extraction with ridge preservation using mineralized human bone allograft. J Periodontol 2010;81(12):17651772.

Becker W, Becker BE, Caffesse R. A comparison of demineralized freeze-dried bone and autologous bone to induce bone formation in human extraction sockets. $\mathrm{J}$ Periodontol 1994;65(12): 1128-1133.

Becker W, Clokie C, Sennerby L, Urist MR, Becker BE. Histologic findings after implantation and evaluation of different grafting materials and titanium micro screws into extraction sockets. Case reports. J Periodontol 1998;69(4):414-421.

Becker W, Urist M, Becker BE, Jackson W, Parry DA, Bartold M, Vincenzzi G, De Georges D, Niederwanger M. Clinical and histologic observations of sites implanted with intraoral autologous bone grafts or allografts. 15 human case reports. J Periodontol 1996;67(10): 1025-1033.

Berglundh T, Lindhe J, Jonsson K, Ericsson I. The topography of the vascular systems in the periodontal and peri-implant tissues in the dog. J Clin Periodontol 1994;21(3): 189. 193.

Bernimoulin JP, Luscher B, Mühlemann HR. Coronally repositioned periodontal flap. Clinical evaluation after one year. J Clin Periodontol 1975;2:1-13.

Botticelli D, Berglundh T, Lindhe J. Resolution of bone defects of varying dimension and configuration in the marginal portion of the peri-implant bone. An experimental study in the dog. J Clin Periodontol 2004;31(4):309-317.

Botticelli D, Berglundh T, Persson LG, Lindhe J. Bone regeneration at implants with turned or rough surfaces in self-contained defects. An experimental study in the dog. $J$ Clin Periodontol 2005;32(5):448-455.

Boyne PJ. Osseous repair of the postextraction alveolus in man. Oral Surg Oral Med Oral Pathol 1966;21(6):805-813.

Brkovic BM, Prasad HS, Konandreas G, Milan R, Antunovic D, Sandor GK, Rohrer MD. Simple preservation of a maxillary extraction socket using beta-tricalcium phosphate with type I: Preliminary clinical and histomorphometric observations. J Can Dent Assoc $2008 ; 74(6): 523-528$.

Brkovic BM, Prasad HS, Rohrer MD, Konandreas G, Agrogiannis G, Antunovic D, Sandor GK. Beta-tricalcium phosphate/type I collagen cones with or without a barrier 
membrane in human extraction socket healing: clinical, histologic, histomorphometric, and immunohistochemical evaluation. Clin Oral Invest 2012;16(2):581-590.

Brownfield LA, Weltman RL. Ridge preservation with or without an osteoinductive allograft: A clinical, radiographic, micro-computed tomography, and histologic study evaluating dimensional changes and new bone formation of the alveolar ridge. $J$ Periodontol 2012;83(5):581-589.

Brugnami F, Caiazzo A. Efficacy evaluation of a new buccal bone plate preservation technique: a pilot study Int J Periodontics Restorative Dent 2011;31(1):67-73.

Brugnami F, Then PR, Moroi H, Kabani S, Leone CW. GBR in human extraction sockets and ridge defects prior to implant placement: Clinical results and histologic evidence of osteoblastic and osteoclastic activities in DFDBA. Int J Periodontics Restorative Dent 1999:19(3):259-268.

Brugnami F, Then PR, Moroi H, Leone CW. Histologic evaluation of human extraction sockets treated with demineralized freeze-dried bone allograft (DFDBA) and cell occlusive membrane. J Periodontol 1996;67(8):821-825.

Burchardt H. The biology of bone graft repair. Clin Orthop Relat Res 1983;174:28-42.

Camargo PM, Lekovic V, Weinlaender M, Klokkevold PR, Kenney EB, Dimitrijevic B, Nedic M. Jancovic S, Orsini M. Influence of bioactive glass on changes in alveolar process dimensions after exodontia. Oral Surg Oral Med Oral Pathol Oral Radiol Endod 2000;90(5):581-586.

Cardaropoli D, Cardaropoli G. Preservation of the postextraction alveolar ridge: A clinical and histologic study. J Periodont Res 2008;28:469-477.

Cardaropoli D, Tamagnone L, Roffredo A, Gaveglio L, Cardaropoli G. Socket preservation using bovine bone mineral and collagen membrane: $A$ randomized controlled clinical trial with histologic analysis Int $\mathrm{J}$ Periodontics Restorative Dent 2012;32(4):421-430.

Cardaropoli G, Araujo M, Lindhe J. Dynamics of bone tissue formation in tooth extraction sites. An experimental study in dogs. J Clin Periodontol 2003;30(9):809-818.

Carmagnola D, Berglundh T, Araujo M, Albrektsson T, Lindhe J. Bone healing around implants placed in a jaw defect augmented with Bio-Oss. An experimental study in dogs. J Clin Peridontol 2000;27(11):799-805.

Checchi V, Savarino L, Montevecchi M, Felice P, Checchi L. Clinical-radiographic and histological evaluation of two hydroxyapatites in human extraction sockets: a pilot study Int J Oral Maxillofac Implants 2011;40(5):526-532. 
Clafin R. Healing of disturbed and undisturbed extraction sites. J Am Dent Assoc 1936;23(6):945-959.

Clagett DR. Ridge augmentation comparing a cancellous block allograft to a moldable allograft paster using an acellular dermal matrix barrier membrane: A clinical and histologic study in humans. [Thesis|. 2006. Louisville, Kentucky. University of Louisville.

Cordini F. Ridge augmentation comparing cancellous block allograft to demineralized bone matrix and utilizing an acellular dermal matrix as a barrier membrane. [Thesis]. 2004. Louisville, Kentucky. University of Louisville.

Crespi R, Capparè P, Gherlone E. Magnesium-enriched hydroxyapatite compared to calcium sulfate in the healing of human extraction sockets: radiographic and histomorphometric evaluation at 3 months. J Periodontol 2009;80(2):210-218.

Crespi R, Cappare P, Gherlone E. Comparison of magnesium-enriched hydroxyapatite and porcine bone in human extraction socket healing: A histologic and histomorphometric evaluation. Int J Oral Maxillofac Implants 2011 b;26(5): 1057-1062.

Crespi R, Cappare P, Romanos GE, Mariani E, Benasciutti E, Gherlone E. Corticocancellous porcine bone in the healing of human extraction sockets: Combining histomorphometry with osteoblast gene expression profiles in vivo. Int J Oral Maxillofac Implants $2011 \mathrm{a} ; 26(4): 866-872$.

Dib Z. Ridge augmentation comparing a cancellous block allograft to a demineralized bone matrix plug plus mineralized particulate allograft covered with an acellular dermal matrix barrier. |Thesis|. 2007. Louisville, Kentucky. University of Louisville.

Engler-Hamm D, Cheung WS, Yen A, Stark PC, Griffin T. Ridge preservation using a composite bone graft and a bioabsorbable membrane with and without primary wound closure: A comparative clinical trial. J Periodontol 201 1;82(3):377-387.

Evian C, Rosenberg E, Coslet $\mathrm{J}$, Corn $\mathrm{H}$. The osteogenic activity of bone removed from healing extraction sockets in humans. J Periodontol 1982;53(2):81-85.

Fernandes PG, Novaes AB Jr, de Queiroz AC, de Souza SL, Taba M Jr, Palioto DB, Grisi MF. Ridge preservation with acellular dermal matrix and anorganic bone matrix cellbinding peptide P-15 after tooth extraction in humans. J Periodontol 201 1;82(1):72-79.

Festa VM, Addabbo F, Laino L, Femiano F, Rullo R. Porcine-derived xenograft combined with a soft cortical membrane versus extraction alone for implant site development: A clinical study in humans. Clin Implant Dent Relat Res 2011; Epub ahead of print $1-7$. 
Fotek PD, Neiva RF, Wang HL. Comparison of dermal matrix and polytetrafluoroethylene membrane for socket bone augmentation: a clinical and histologic study. J Periodontol 2009;80(5):776-785.

Froum S, Cho S, Rosenberg E, Rohrer M, Tarnow D. Histologic comparison of healing extraction sockets implanted with bioactive glass or demineralized freeze-dried bone allograft: A pilot study. J Periodontol 2002;73(1):94-102.

Froum S, Cho SC, Elian N, Rosenberg E, Rohrer M, Tarnow D. Extraction sockets and implantation of hydroxyapatites with membrane barriers a histologic study. Implant Dent 2004;13(2):153-161.

Garg AK. Alveolar ridge preservation during and after surgical tooth removal. Dent Implantol Update 2001;11(8):57-62.

Gholami GA, Najafi B, Mashhadiabbas F, Goetz W, Najafi S. Clinical, histologic and histomorphometric evaluation of socket preservation using a synthetic nanocrystalline hydroxyapatite in comparison with a bovine xenograft: a randomized clinical trial Clin Oral Implants Res 2011; Epub ahead of print 1-7.

Goldberg VM, Stevenson S. The biology of bone grafts. Semin Arthroplasty 1993;4(2):58-63.

Guarnieri R, Pecora G, Fini M, Nicoli Aldini N, Giardino R, Orsini G, Piattelli A. Medical grade calcium sulfate hemihydrate in healing of human extraction sockets: Clinical and histological observations at 3 months. J Periodontol 2004;75(5):902-908.

Heberer S, Al-Chawaf B, Jablonski C, Nelson JJ, Lage H, Nelson K. Healing of ungrafted and grafted extraction sockets after 12 weeks: a prospective clinical study Int $\mathrm{J}$ Oral Maxillofac Implants 2011 ;26:385-392.

Hoang TN, Mealey BL. Histologic comparison of healing after ridge preservation using human demineralized bone matrix putty with one versus two different-sized bone particles. J Periodontol 2012;83(2):174-181.

Horowitz RA. Extraction environment enhancement: Critical evaluation of early socket healing in long-term barrier protected extraction sockets. Compend Contin Educ Dent $2005 ; 26(10): 703-713$.

Iasella JM, Greenwell H, Miller RL, Hill M, Drisko C, Bohra AA, Scheetz JP. Ridge preservation with freeze dried bone allograft and a collagen membrane compared to extraction alone for implant site development: A clinical and histologic study in humans. J Periodontol 2003;74(7):988-997. 
Kotevska $\mathrm{V}$. Ridge preservation comparing the clinical and histologic healing of a demineralized particulate bone allograft vs. mineralized particulate cancellous allograft using a barrier membrane. |Thesis|. Louisville, Kentucky. University of Louisville. 2011.

Kutkut A, Andreana S, Kim HL, Monaco E Jr. Extraction socket preservation graft before implant placement with calcium sulfate hemihydrate and platelet-rich plasma: A clinical and histomorphometric study in humans. J Periodontol 2012;83(4):401-409.

Lahey B. Ridge augmentation comparing cancellous block allograft to particulate freeze dried bone allograft utilizing an acellular dermal matrix barrier membrane. [Thesis]. 2005. Louisville, Kentucky. University of Louisville.

Lekholm U, Zarb GA. Patient selection and preparation. In Branemark P-I, Zarb GA, Albrektsson T, editors: Tissue integrated prostheses: osseointegration in clinical dentistry. Chicago: Quintessence. Book 1985;199-209.

Lekovic V, Camargo PM, Klokkevold PR, Weinlaender M, Kenney EB, Dimitrijevic B, Nedic M. Preservation of alveolar bone in extraction sockets using bioabsorbable membranes. J Periodontol. 1998;69(9):1044-1049.

Lekovic V, Kenney EB, Weinlaender M, Han T, Klokkevold P, Nedic M, Orsini M. A bone regenerative approach to alveolar ridge maintenance following tooth extraction. Report of 10 cases. J Periodontol 1997;68(6):563-570.

Loe $\mathrm{H}$. The gingival index, the plaque index and the retention index systems. $J$ Periodontol 1967;38(Suppl):610-617.

Luczyszyn SM, Papalexiou V, Novaes AB Jr, Grisi MF, Souza SL, Taba M Jr. Acellular dermal matrix and hydroxyapatite in prevention of ridge deformities after tooth extraction. Implant Dent 2005;14(2):176-184.

MacNeill SR, Cobb CM, Rapley JW, Glaros AG, Spencer P. In vivo comparison of synthetic osseous graft materials. A preliminary study. J Clin Periodontol 1999;26(4):239-245.

Mangano C, Piatelli, A, Perrotti V, Iezzi G. Dense hydroxyapatitie inserted into postextraction sockets: A histologic and histomorphometric 20-year case report. J Periodontol 2008;79:929-933.

Mardas $\mathrm{N}$, Chadha $\mathrm{V}$, Donos $\mathrm{N}$. Alveolar ridge preservation with guided bone regeneration and a synthetic bone substitute or a bovine-derived xenograft: A randomized, controlled clinical trial. Clin Oral Implants Res 2010;21(7):688-698.

McAllister BS, Haghighat K, Prasad HS, Roher MD. Histologic evaluation of recombinant human platelet-derived growth factor-BB after use in extraction socket defects: a case series J Periodont Restorative Dent 2010;30:365-373. 
Mellonig J. Freeze-Dried bone allografts in periodontal reconstructive surgery. Dent Clin North Am 1991;35(3):505-520.

Mellonig J, Bowers G, Cotton W. Comparison of bone graft materials. Part II. New bone formation with autografts and allografts: A histological evaluation. J Periodontol $1981 ; 52(6): 297-302$.

Nam HW, Park JB, Lee JY, Rhee SH, Lee SC, Koo KT, Kim TI, Seol YJ, Lee YM, Ku Y, Rhyu IC, Park YJ, Chung CP. Enhanced ridge preservation by bone mineral bound with collagen-binding synthetic oligopeptide: a clinical and histologic study in humans/ $\mathbf{J}$ Periodontol 2011:82(3):471-480.

Neiva RF, Tsao YP, Eber R, Shotwell J, Billy E, Wang HL. Effects of a putty-form hydroxyapatite matrix combined with the synthetic cell-binding peptide $\mathrm{p}-15$ on alveolar ridge preservation. J Periodontol 2008;79:291-299.

Nemcovsky CE, Serfaty V. Alveolar ridge preservation following extraction of maxillary anterior teeth. Report on 23 consecutive cases. J Periodontol 1996;67(4):390-395.

Nevins ML, Camelo M, Schupbach P, Kim DM, Camelo JM, Nevins M. Human histologic evaluation of mineralized collagen bone substitute and recombinant plateletderived growth factor-BB to create bone for implant placement in extraction socket defects at 4 and 6 months: a case series. Int J Periodontics Restorative Dent 2009;29(2): 129-139.

Oghli AA, Steveling $\mathrm{H}$. Ridge preservation following tooth extraction: a comparison between atraumatic extraction and socket seal surgery. Quintessence Int 2010;41(7):605609.

Pelegrine AA, Sorgi da Costa CE, Pizzigatti Correa ME, Comenalli Marques Jr JF. Clinical and histomorphometric evaluation of extraction sockets treated with an autologous bone marrow graft Clinical Oral Implant Research 2010;21:535-542.

Pietrokovski J, Massler M. Alveolar ridge resorption following tooth extraction. J Prosth Dent 1967:17(1):21-27.

Poulias E. Ridge preservation comparing the clinical and histologic healing of an intrasocket allograft vs. a facial overlay xenograft using a bioresorbable barrier membrane. [Thesis]. Louisville, Kentucky. University of Louisville. 2012.

Ratliff MA. Ridge augmentation comparing a mineralized cancellous vs a cortical particluate allograft utilizing an acellular dermal matrix barrier membrane. [Thesis]. 2009. Louisville, Kentucky. University of Louisville. 
Sams M. Ridge preservation comparing the clinical and histologic healing of a mineralized cortical vs. a mineralized cancellous allograft with an acellular dermal matrix barrier membrane. [Thesis|. 2010. Louisville, Kentucky. University of Louisville.

Scarano A, Pecora G, Piattelli M, Piattelli A. Osseointegration in a sinus augmented with bovine porous bone mineral: Histological results in an implant retrieved 4 years after insertion. A case report. J Periodontol 2004;75(8):1161-1166.

Schropp L, Wenzel A, Kostopoulos L, Karring T. Bone healing and soft tissue contour changes following single-tooth extraction: A clinical and radiographic 12 month prospective study. Int J Periodontics Restorative Dent 2003;23(4):313-323.

Schwartz Z, Mellonig JT, Carnes DL Jr, De La Fontaine J, Cochran DL, Dean DD, Boyan BD. Ability of commercial demineralized freeze-dried bone allograft to induce new bone formation. J Periodontol 1996;67(9):918-926.

Schwartz Z, Somers A, Mellonig JT, Carnes DL, Dean DD, Cochran DL, Boyan BD. Ability of commercial demineralized freeze-dried bone allograft to induce new bone formation is dependent on donor age but not gender. J Periodontol 1998;69(4):470-478.

Schwartz Z, Weesner T, van Dijk S, Cochran DL, Mellonig JT, Lohmann CH, Carnes DL, Goldstein M, Dean DD, Boyan BD. Ability of deproteinized cancellous bovine bone to induce new bone formation. J Periodontol 2000;7I(8): 1258-1269.

Serino G, Biancu S, Iezzi G, Piatelli A. Ridge preservation following tooth extraction using a polylactide and polyglycolic sponge as space filler: a clinical and histological study in humans. Clin Oral Implants Res 2003;14(5):651-658.

Silness J, Löe H. Periodontal disease in pregnancy. II. Correlation between oral hygiene and periodontal conditions. Acta Odontol Scand 1964;22(1):121-135.

Simon BI, Von Hagen S, Deasy MJ, Faldu M, Resnansky D. Changes in alveolar bone height and width following ridge augmentation using bone graft and membranes. J Periodontol 2000;71(1):1774-1791.

Siu TL. Ridge preservation comparing a flap vs. flapless technique using a demineralized bone matrix allograft plus mineralized particulate allograft and covered with a calcium sulfate barrier. |Thesis|. Louisville, Kentucky. University of Louisville. 2007.

Smukler H, Landi L, Setayesh R. Histomorphometric evaluation of extraction sockets and deficient alveolar ridges treated with allograft and barrier membrane: A pilot study. Int $\mathrm{J}$ Oral Maxillofac Implants 1999;14(3):407-416.

Stimmelmayr M, Guth JF, Iglhaut G, Beuer F. Preservation of the ridge and sealing of the socket with a combination epithelialised and subepithelial connective tissue graft for 
management of defects in the buccal bone before insertion of implants: a case series $\mathrm{Br} \mathbf{J}$ Oral Maxillofac Surg 2012;50(6):550-555.

Tagge DL, O'Leary TJ, El-Kafrawy $\mathrm{AH}$. The clinical and histological response of periodontal pockets to root planing and oral hygiene. J Periodontol 1975;46(9):527-533.

Toloue SM, Chesnoiu-Matei I, Blanchard SB. A clinical and histomorphometric study of calcium sulfate compared to freeze dried bone allograft (FDBA) for alveolar ridge preservation. J Periodontol $2011 ; 83(7): 847-855$.

Urist M. Bone: Formation by autoinduction. Science 1965;150(698):893-899.

Urist MR, Strates BS. Bone morphogenetic protein. J Dent Res 1971;50(9):1392-1406.

Vance GS, Greenwell H, Miller RL, Hill M, Johnston H, Scheetz JP. Comparison of an allograft in an experimental putty carrier and a bovine-derived xenograft used in ridge preservation: A clinical and histologic study in humans. Int $\mathbf{J}$ Oral Maxillofac Implants 2004;19(4):491-497.

Wallace SS, Froum SJ, Cho S-C, Elian N, Monteior D, Kim BS, Tarnow DP. Sinus augmentation utilizing anorganic bovine bone (Bio-Oss) with absorbable and nonabsorbable membranes placed over the lateral window: Histomorphometric and clinical analyses. Int J Periodontics Restorative Dent 2005;25(6):551-560.

Wang HL, Misch C, Neiva RF. "Sandwich" bone augmentation technique: Rationale and report of pilot cases. Int J Periodontics Restorative Dent 2004;24(3):232-245.

Wang HL, Tsao JP. Histologic evaluation of socket augmentation with mineralized human allograft. Int J Periodontics Restorative Dent 2008;28(3):231-237.

Witonsky J. Ridge preservation comparing the clinical and histologic healing of a mineralized particulate allograft with a nonporous PTFE membrane vs. mineralized particulate xenograft with a collagen plug membrane. |Thesis|. 2009. Louisville, Kentucky. University of Louisville.

Woelfel JB. Dental Anatomy: Its Relevance to Dentistry. Fourth Edition . Philadelphia: Lea \& Febiger. Book 1990.

Wood RA, Mealey BL. Histologic comparison of healing after tooth extraction with ridge preservation using mineralized versus demineralized freeze-dried bone allograft. J Periodontol 2012;83(3):329-336.

Yilmaz S, Efeoglu E, Kilic AR. Alveolar ridge reconstruction and/or preservation using root form bioglass cones. J Clin Periodontol 1998;25(10):832-839. 
Zitzmann NU, Scharer P, Marinello CP, Schupbach P, Berglundh T. Alveolar rdige augmentation with Bio-Oss: A histologic study in humans. Int J Periodontics Restorative Dent $2001 ; 21(3): 289-296$.

Zubillaga G, Von Hagen S, Simon BI, Deasy MJ. Changes in alveolar bone height and width following post-extraction ridge augmentation using a fixed bioabsorbable membrane and demineralized freeze-drired bone osteoinducive graft. J Periodontol 2003;74(7):965-975. 


\section{Appendix A}

\section{The Plaque Index}

The plaque index of Silness and Loe (1964) was measured. Scores were as follows:

0 - No plaque

I - A film of plaque adhering to the free gingival margin and adjacent area of the tooth.

The plaque may be seen in situ only after application of disclosing solution or by using the probe on the tooth surface.

2 - Moderate accumulation of soft deposits within the gingival pocket, or on the tooth and gingival margin, which can be seen with the naked eye.

3 - Abundance of soft matter within the gingival pocket and/or on the tooth and gingival margin.

Each gingival unit (buccal, lingual, mesiobuccal, distobuccal, mesiolingual, and distolingual) of the study tooth was given a score from $0-3$, called the plaque index for the area. The scores from the 6 areas of the tooth were added and divided by 6 to give the plaque index for the tooth. 


\section{Appendix B}

\section{Gingival Index}

The gingival index of Loe (1967) was measured for the extracted tooth and any adjacent teeth. Scores were be recorded as follows:

$0=$ Normal gingiva .

$1=$ Mild inflammation - slight change in color slight edema, no bleeding on probing. 2 = Moderate inflammation - redness, edema, and glazing, bleeding on probing. 3 = Severe inflammation - marked redness and edema, ulceration and tendency to spontaneous bleeding.

Each gingival unit (mesiobuccal, buccal, distobuccal, distolingual, lingual, mesiolingual) of the tooth was given a score $0-3$. The scores for each unit were added together and divided by 6 to give the gingival index for that tooth. The score of the test tooth and the two adjacent teeth were added and divided by 3 to give the gingival index for the test of control sites. 


\section{Appendix C}

\section{Bleeding on Probing Index}

Tagge et al. (1975) reported on the use of an index of bleeding upon probing to show the amount of hemorrhage within the periodontal sulcus. The following is the index used to record bleeding on probing:

\footnotetext{
$0=$ No bleeding

$1=$ Mild - a bleeding point appearing 10 to 30 seconds after withdrawing the probe.

$2=$ Moderate - bleeding when probing produces an almost immediate, but noncontinuous bleeding.

$3=$ Severe - bleeding when gentle probing elicits immediate and continuous bleeding.
} 


\section{Appendix D}

\section{Standardized Radiographic technique}

An occlusal stent was used to provide a stable foundation for the radiograph holder. A light cured resin material was placed on a Rinn radiograph holder and positioned to allow as near as possible paralleling technique. This material was light cured so that standardized radiographs can be compared. Radiographs were taken at baseline and 4 months. 


\section{Appendix E}

\section{$\underline{\text { Arithmetic determinations: }}$}

Ridge width (Post-extraction) $=$ A digital caliper was used to measure total mid-socket ridge width to the nearest $10^{-2} \mathrm{~mm}$ at the alveolar crest and $5 \mathrm{~mm}$ from the alveolar crest.

Ridge width (4 month re-entry) = Again, a digital caliper measured total ridge width to the nearest $10^{-2} \mathrm{~mm}$ at one point, mid socket, at the alveolar crest and $5 \mathrm{~mm}$ from the alveolar crest.

Change in alveolar crest height $=$ Initial: stent to alveolar crest minus re-entry stent to alveolar crest. 


\section{Appendix F}

\section{$\underline{\text { Stent fabrication }}$}

Rigid stents were made of $3 \mathrm{~mm}$ thick light cured resin material in order to provide reproducible measurements. The tooth to be extracted was ground off the model and the light cured resin material was pressed over a cast. Three channels were prepared on the labial and three on the palato/lingual aspect of the stent in which a North Carolina periodontal probe was placed so that mesial, mid and distal measurements could be made on the labial and palato/lingual aspects of the crestal bone. Additionally, two channels were also prepared on the occlusal portion of the stent to provide measures of mesial and distal occlusal ridge height. Holes were prepared with a high-speed hand-piece. In this way, reproducible probing spots and directions of probe insertions were possible. 


\title{
CURRICULUM VITAE
}

\author{
Evmenios Poulias, DDS, MS
}

\section{EDUCATION}

2009-2012 University of Louisville Graduate Periodontics

Certificate in Periodontics

2009-2012 University of Louisville

Master of Science in Oral Biology

2008 University of Athens, Greece, School Dental Dentistry

Doctor Dental Surgery (D.D.S)

\section{LICENSURE}

February 2008-Present Greek Dental License

June 2009-Present Kentucky Dental License

Category II Laser certification 2009

ACLS certification 2009

\section{PROFESSIONAL ASSOCIATIONS}

Hellenic Dental Association membre

American Academy of Periodontology member 
Academy of Osseointegration member

Kentucky Dental Association member

\section{EXTERNSHIPS}

Internal Medicine Rotation, University of Louisville Hospital, June 2010

Anesthesiology Rotation, University of Louisville Hospital, May 2010 